\title{
Mass spectrometry-based quantitative proteomic analysis of Salmonella enterica serovar Enteritidis protein expression upon exposure to hydrogen peroxide
}

\author{
Kihoon Kim¹, Edward Yang ${ }^{1}$, Gia-Phong Vu¹, Hao Gong², Jing Su², Fenyong Liu*1,2 and Sangwei Lü1,2
}

\begin{abstract}
Background: Salmonella enterica, a common food-borne bacterial pathogen, is believed to change its protein expression profile in the presence of different environmental stress such as that caused by the exposure to hydrogen peroxide $\left(\mathrm{H}_{2} \mathrm{O}_{2}\right)$, which can be generated by phagocytes during infection and represents an important antibacterial mechanism of host cells. Among Salmonella proteins, the effectors of Salmonella pathogenicity island 1 and 2 (SPI-1 and SPI-2) are of particular interest since they are expressed during host infection in vivo and are important for invasion of epithelial cells and for replication in organs during systemic infection, respectively. However, the expression profiles of these proteins upon exposure to $\mathrm{H}_{2} \mathrm{O}_{2}$ or to host cells in vivo during the established phase of systemic infection have not been extensively studied.
\end{abstract}

Results: Using stable isotope labeling coupled with mass spectrometry, we performed quantitative proteomic analysis of Salmonella enterica serovar Enteritidis and identified 76 proteins whose expression is modulated upon exposure to $\mathrm{H}_{2} \mathrm{O}_{2}$. SPI-1 effector SipC was expressed about 3-fold higher and SopB was expressed approximately 2-fold lower in the presence of $\mathrm{H}_{2} \mathrm{O}_{2}$, while no significant change in the expression of another SPI-1 protein SipA was observed. The relative abundance of SipA, SipC, and SopB was confirmed by Western analyses, validating the accuracy and reproducibility of our approach for quantitative analysis of protein expression. Furthermore, immuno-detection showed substantial expression of SipA and SipC but not SopB in the late phase of infection in macrophages and in the spleen of infected mice.

Conclusions: We have identified Salmonella proteins whose expression is modulated in the presence of $\mathrm{H}_{2} \mathrm{O}_{2}$. Our results also provide the first direct evidence that SipC is highly expressed in the spleen at late stage of salmonellosis in vivo. These results suggest a possible role of $\mathrm{SipC}$ and other regulated proteins in supporting survival and replication of Salmonella under oxidative stress and during its systemic infection in vivo.

\section{Background}

Salmonella enterica is one of the leading causes of foodborne illnesses around the world [1,2]. There are two major serotypes of Salmonella enterica, namely Salmonella enterica serovar Enteritidis ( $S$. Enteritidis) and Typhimurium (S. Typhimurium). In recent years, $S$.

\footnotetext{
*Correspondence: liu_fy@uclink4.berkeley.edu, sangwei@berkeley.edu

1 Program in Comparative Biochemistry, University of California, Berkeley, CA 94720, USA

2 Division of Infectious Diseases and Vaccinology, School of Public Health, University of California, Berkeley, CA 94720, USA

Full list of author information is available at the end of the article
}

Enteritidis represents one of the most commonly reported serotypes associated with food poisoning illness in the United States [3]. Two hallmarks of Salmonella pathogenesis are the invasion of non-phagocytic cells such as the epithelial cells of the intestinal mucosa, and the survival inside macrophages during systemic infection. The mechanisms of both processes are linked to the functions of two type III secretion systems (T3SS) of Salmonella that are encoded and regulated by a cluster of genes at the Salmonella Pathogenicity Island 1 and 2 (SPI-1 and SPI-2), respectively. It is believed that SPI-1 
T3SS is responsible for invasion of non-phagocytic cells, while SPI-2 T3SS is essential for intracellular replication and systemic infection $[4,5]$.

In order to survive and replicate in an aerobic environment, organisms including Salmonella must cope with reactive oxygen species such as hydrogen peroxide $\left(\mathrm{H}_{2} \mathrm{O}_{2}\right)$, which are formed in respiring cells as incomplete reduction products of molecular oxygen, and which can cause damage to DNA, RNA, protein, and lipids [6-8]. To respond to oxidative stress, bacteria activate a set of globally regulated genes, including two known stimulons: peroxide stimulons and superoxide stimulons [7,9-12].

The response of Salmonella to oxidative stress represents a key component of its pathogenesis [7,9]. Reactive oxygen species generated by the NADPH phagocytic oxidase system in phagocytes play an important role in controlling Salmonella replication in macrophages and systemic infection in the spleen $[13,14]$. To combat the damaging effects of this oxidative stress and survive in macrophages during systemic infection such as in the spleen, it is believed that Salmonella uses unique strategies and expresses specific proteins to carry out defense and repair functions $[7,9]$. While little is known about the expression of SPI-1 factors upon oxidative stress, several SPI-1 factors SipA, SopA, SopB, SopD, and SopE2 of S. Typhimurium were found to be expressed in the spleen of infected animals at the late stages of infection when Salmonella is believed to replicate in splenic macrophages $[15,16]$. These results suggest that in addition to their generally recognized roles in invasion, the SPI-1 factors may also play an important role post-invasion, including a possible role in resistance to the oxidative stress generated by tissue macrophages. An understanding of the expression profiles of Salmonella SPI-1 factors and other proteins in the presence of reactive oxygen species such as $\mathrm{H}_{2} \mathrm{O}_{2}$ should provide insight into the identification of virulent determinants important for Salmonella to survive in macrophages and cause systemic infection in the spleen in vivo.

The expression of Salmonella genes (including those encoding SPI-1 factors) in vitro under various conditions has been extensively studied [17-21]. However, most of these studies were performed by examining the transcription levels of Salmonella genes either using microarray or a reporter system $[17,19-23]$. Recently, proteomic analysis of Salmonella protein expression in the spleen of infected animals has been reported [24]. Furthermore, Smith and co-workers have reported global protein profiles of Salmonella enterica serovars Typhimurium and Typhi cultured at the stationary phase, logarithmic (log) phase, or phagosome-mimicking culture conditions, and the expression profiles of proteins in infected macrophages [25-28]. However, to our knowledge, global expression profiling of Salmonella proteins upon exposure to reac- tive oxygen species such as $\mathrm{H}_{2} \mathrm{O}_{2}$ has not been reported, and efforts to identify proteins whose expression levels are affected by oxidative stress have been limited mostly to a few proteins at a time $[9,29,30]$. In addition, expression of Salmonella proteins including those of SPI-1 in vivo during the established phase of infection has not been extensively studied.

In this study, we have modified the procedure of Stable Isotope Labeling by Amino acids in Cell culture (SILAC) $[31,32]$ to develop a mass spectrometry (MS)-based approach to carry out quantitative proteomic analysis of Salmonella. Using this procedure, we have identified 76 proteins from a strain of Salmonella enterica serovar Enteritidis that are differentially regulated upon exposure to $\mathrm{H}_{2} \mathrm{O}_{2}$. The results on selected SPI-1 proteins were confirmed by Western blot analyses, validating the accuracy and reproducibility of our approach for quantitative analyses of protein expression. The expression of several SPI1 proteins was further analyzed in infected macrophages and in the spleen of infected mice. These results suggest a possible role for SPI-1 proteins in Salmonella infection in the presence of oxidative stress and in systemic infection in an animal host.

\section{Results}

Stable isotope labeling of Salmonella with ${ }^{15} \mathrm{~N}$-containing growth media

We used a virulent clinical isolate of Salmonella enterica serovar Enteritidis SE2472 for this analysis. Our previous studies have shown that almost all clinical strains analyzed, including SE2472, exhibited similar levels of resistance to $\mathrm{H}_{2} \mathrm{O}_{2}$ [33]. We chose this strain to examine the expression profiles of Salmonella proteins upon exposure to $\mathrm{H}_{2} \mathrm{O}_{2}$, a stress condition relevant to what Salmonella may encounter in macrophages and in the spleen during bacterial infection in vivo. To determine protein levels in two or more different biological states (e.g. in the absence and presence of $\mathrm{H}_{2} \mathrm{O}_{2}$ ), we modified the SILAC procedure (Figure 1) in which the introduction of a stable isotope ${ }^{15} \mathrm{~N}$ into the protein mixture provides a means to quantitatively analyze two sets of protein mixtures simultaneously [31,32]. Stable isotope-based quantification relies on the premise that the relative signal intensity of two analytes that are chemically identical but different in stable isotope compositions can be resolved in a mass spectrometer, thus giving a true measure of the relative abundance of the analytes $[31,32,34,35]$. To determine the efficiency of the labeling and incorporation of the heavy isotope, SE2472 was grown in ${ }^{15} \mathrm{~N}$-containing LB brothlike media. SE2472 appeared to grow in the normal $\left({ }^{14} \mathrm{~N}\right)$ and ${ }^{15} \mathrm{~N}$-containing LB broth-like media as well as in the LB broth as they reach similar titers in these media (data not shown). Bacteria were harvested at different time 


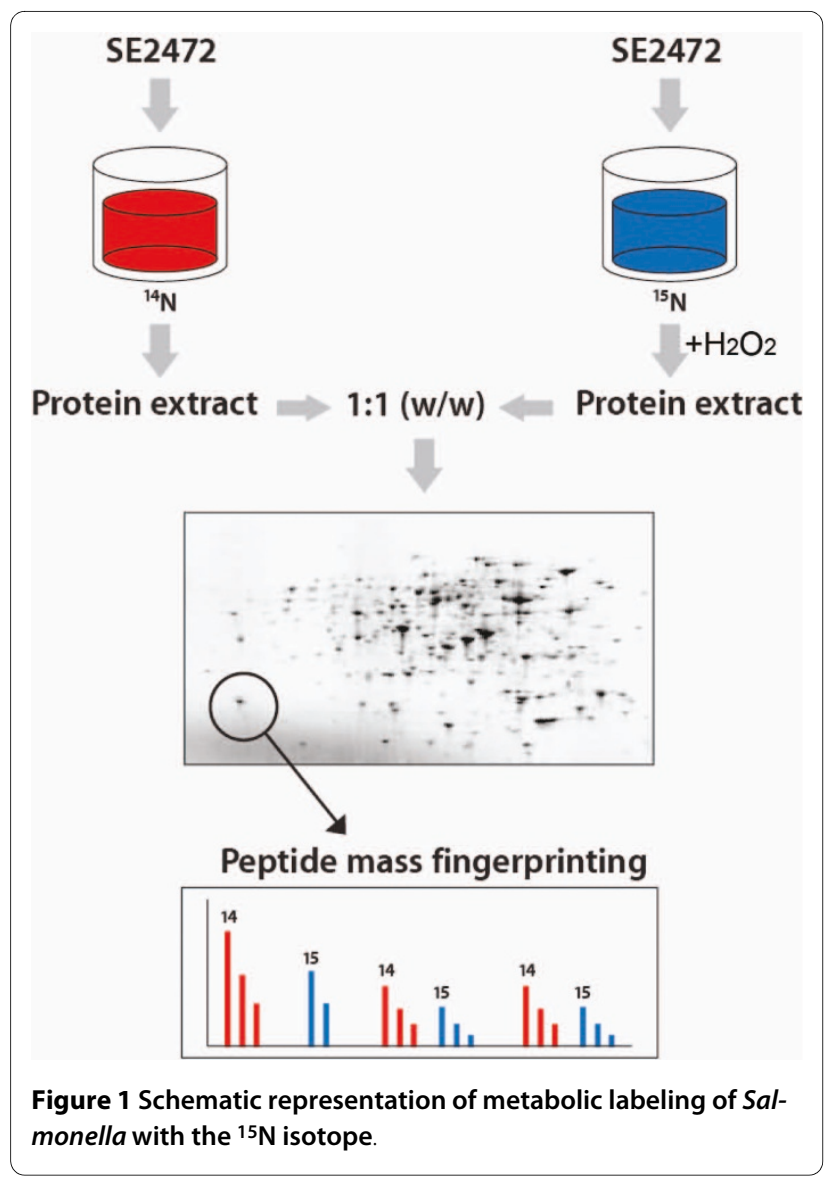

points and the extent of ${ }^{15} \mathrm{~N}$-labeling of Salmonella proteins was examined by MS analysis in comparison to the control ${ }^{14} \mathrm{~N}$ labeled bacteria. Growth in ${ }^{15} \mathrm{~N}$-labeled media for 6 hours or more was sufficient to label the entire Salmonella proteome with ${ }^{15} \mathrm{~N}$ (data not shown). The proteins examined and all the peptides of each protein appeared to have identical incorporation rate. Accordingly, all labeling experiments were carried out for at least 6 hours in this study.

\section{Wild type-like growth phenotypes of labeled bacteria}

One of our main objectives in the study was to use the expression of the labeled proteins to monitor Salmonella protein levels when Salmonella is exposed to oxidative stress. Thus, it is necessary to determine whether ${ }^{15} \mathrm{~N}$ labeled Salmonella retain the growth and oxidative stress-resistant properties of the unlabeled SE2472 in vitro. ${ }^{15} \mathrm{~N}$-labeled Salmonella appeared to grow as well as the unlabeled bacteria in LB broth (Figure 2A). No detectable difference in the colony size and morphology was observed between these two cultures. Furthermore, no difference was detected between the survival of the $\mathrm{N}^{14}$ - and $\mathrm{N}^{15}$-labeled bacteria in either the LB broth-like labeling media or the LB broth in the presence of $5 \mathrm{mM}$ $\mathrm{H}_{2} \mathrm{O}_{2}$, a concentration well below the minimal inhibition

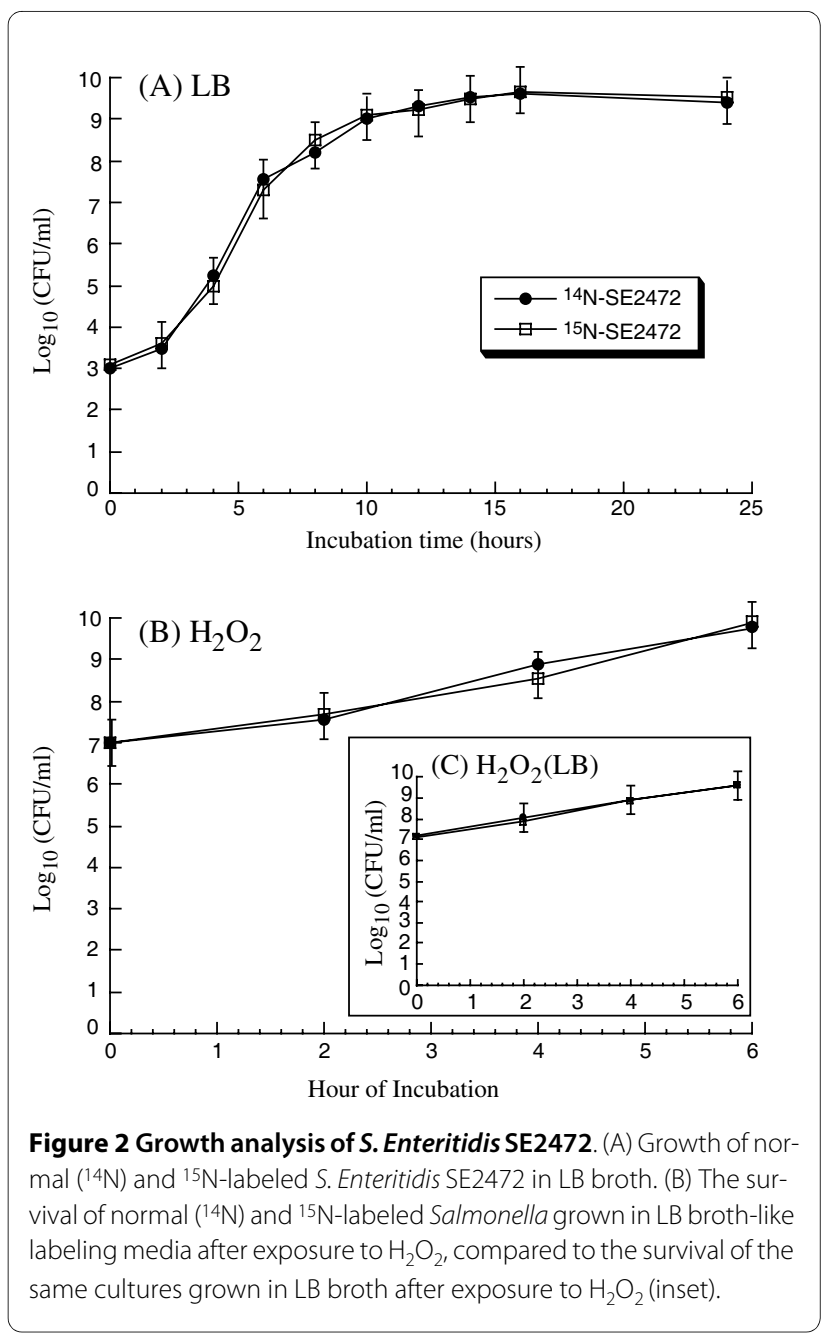

concentration (MIC) of SE2472 (20 mM) but substantially above the natural extracellular environment (Figure 2B).

\section{Quantitative proteomic analyses of Salmonella protein expression}

To investigate the expression profiles of Salmonella upon exposure to oxidative stress, single colonies of SE2472 were grown in ${ }^{14} \mathrm{~N}$ - or ${ }^{15} \mathrm{~N}$-containing LB broth-like media and only the ${ }^{15} \mathrm{~N}$ culture was treated with $5 \mathrm{mM}$ $\mathrm{H}_{2} \mathrm{O}_{2}$ for 2 hours to simulate the oxidative stress condition (Figure 1). Total proteins from the ${ }^{14} \mathrm{~N}$ - and ${ }^{15} \mathrm{~N}$ samples were extracted and quantified. A 1:1 (by weight) mixture of two samples was prepared and $200 \mu \mathrm{g}$ of total proteins were separated by two-dimensional (2-D) gel electrophoresis. Visualization by silver staining revealed approximately 200 protein spots across the $\mathrm{pI}$ and molecular weight range of the gel, which were further investigated using quantitative proteomics (Figure 3).

Analysis with matrix-assisted laser desorption/ionisation-time of flight (MALDI-ToF) mass spectrometry was 


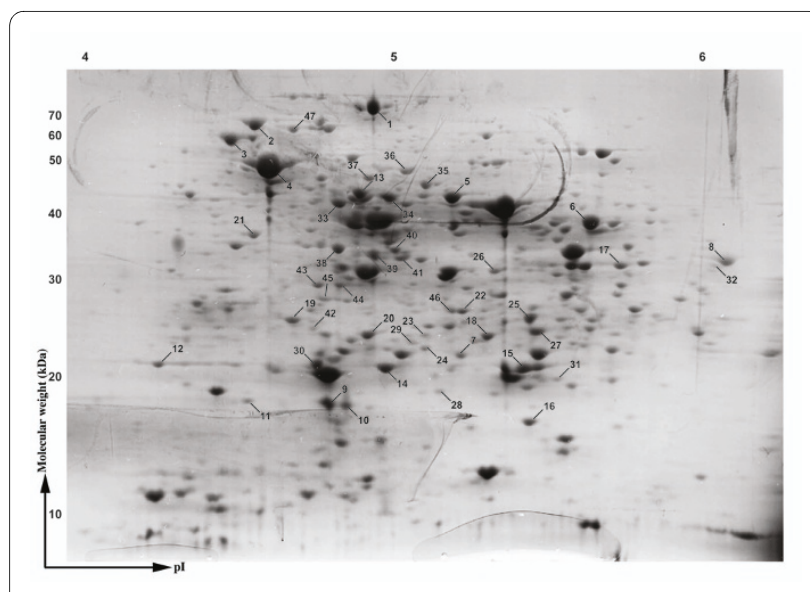

Figure 3 Two-dimensional gel electrophoresis of S. Enteritidis SE2472 total proteins. Approximately $200 \mu \mathrm{g}$ of total SE2472 proteins were loaded onto a $2 \mathrm{D}$ gel and visualized by the silver staining method.

performed to map tryptic fragments from the mixture of the ${ }^{14} \mathrm{~N}$ - and ${ }^{15} \mathrm{~N}$-(unexposed and $\mathrm{H}_{2} \mathrm{O}_{2}$-exposed) samples, where two sets of peptide fingerprints appear on the same spectrum (Figure 4, Table 1). We distinguished the two sets of peaks by initially using the ${ }^{14} \mathrm{~N}$ peaks to identify the protein and amino acid contents of each peak (Figure 4 and Table 1), then using peak information to deduce the location of the ${ }^{15} \mathrm{~N}$ peaks. The ratio of the peak heights $\left({ }^{15} \mathrm{~N} /{ }^{14} \mathrm{~N}\right)$ was then used for relative quantification (Figures 1 and 4). Figure 4 shows an example taken from a protein sample, a tryptic peptide fragment FTGWYDVDLSEK (MW 1459.81) from S. Enteritidis phosphoglyceromutase. A peak at $\mathrm{m} / \mathrm{z} 1473$ represents the ${ }^{15} \mathrm{~N}$-labeled population (Figure 4 , upper spectrum), which does not appear in the unlabeled population. The ratio of two peak intensities (27 and 17, respectively) represents a relative protein expression level of 0.6 , or a $40 \%$ downregulation. To further increase the accuracy of our results, each set of experiments was repeated three times. Only those proteins that were detected and identified with high confidence in all three independent experiments are listed in Table 2.

\section{Automation of expression profiling}

Predicting the location of ${ }^{15} \mathrm{~N}$ peaks for any given peptide was a two-step process. First, the protein was identified and the amino acid contents of each peak were searched using the MASCOT software. Based on the number of nitrogen atoms in the peptide, a prediction was then made as to the molecular weight of the ${ }^{15} \mathrm{~N}$ peaks. To facilitate this process, we developed a custom VBScript for Microsoft Excel that automatically predicts ${ }^{15} \mathrm{~N}$ peak locations with a simple copy and paste feature. Using this script, many sets of peak data can be processed within minutes, virtually eliminating the need to manually inspect each peak for the number of nitrogen atoms.

Using the developed program, we generated a list of 103 SE2472 proteins and their expression profiles upon exposure to $\mathrm{H}_{2} \mathrm{O}_{2}$ (Table 1 and 2). All these proteins were detected and identified with high confidence in all three independent experiments. We should note that the absence of a protein in our results does not necessarily mean it was not expressed and/or induced; instead its expression status is yet to be determined. The majority of protein expression was up-regulated, albeit at different levels. We further categorized proteins into different groups based on their functions, as shown in Table 3. Interestingly, SipC and SopB, which are the SPI-1 translocase and effector, were differentially expressed in the presence of $\mathrm{H}_{2} \mathrm{O}_{2}$. SipC was about 3-fold higher and SopB was 2-fold lower in the exposed samples, while no significant change in the expression of another SPI-1 protein SipA was observed (Table 2 and 3 ).

\section{Validation of differential expression of the SPI-1 proteins}

To demonstrate the validity of our proteomic results, we examined the relative abundance of SipA, SipC, and SopB by Western blot analysis. Salmonella strains SipA(HF), $\operatorname{SipC}(\mathrm{HF})$ and $\operatorname{SopB}(\mathrm{HF})$ were derived from SE2472 and contained a FLAG epitope tag sequence at the carboxyl terminus of $\operatorname{sip} A, \operatorname{sip} C$ and $\operatorname{sop} B$, respectively [36]. The tagged strains grew in LB broth as well as the parental strain SE2472, indicating that the insertion of the tag sequence did not significantly affect bacterial growth in vitro [36](data not shown). To study the pathogenesis of the tagged strains in oral and systemic infection, we infected BALB/c mice intragastrically and intraperitoneally with the tagged Salmonella strains and compared infected mice to those infected with the wild type SE2472. The survival of infected mice and the colonization of spleen, liver, and ileum of the infected mice by Salmonella were determined at different time points post infection. For BALB/c mice infected intragastrically with $1 \times 10^{6} \mathrm{CFU}$ of the tagged or the wild type strains, all infected mice died within 7 days post infection and no significant difference was observed among the wild type and the tagged strains (Figure 5A). No significant difference in the colonization of the internal organs such as spleen, liver, and ileum, was observed between the parental (wild type) SE2472 strain and the tagged strains regardless of the route of inoculation (Table 4). These results suggest that tagging of the target ORF does not impair the invasiveness, growth, and virulence of the bacteria, and that the tagged strains can be used as model strains to study infection of Salmonella in vitro and in vivo, including the expression of the SPI-1 proteins.

To determine the effect of $\mathrm{H} 2 \mathrm{O} 2$ on the expression of the tagged ORFs, bacterial strains were grown in LB 
Table 1: MALDI-ToF analysis and identification of SE2472 proteins.

\begin{tabular}{|c|c|c|c|c|c|}
\hline $\begin{array}{l}\text { Locus } \\
\text { Tag }\end{array}$ & Description & Gene & $\begin{array}{l}\text { Mass } \\
\text { (KDa) }\end{array}$ & pl & Coverage \\
\hline PSLT011 & Dlp (SrgA) & $\operatorname{srg} A$ & 24.74 & 8.58 & $38 \%$ \\
\hline STM0007 & Transaldolase B & talB & 35.15 & 5.09 & $19 \%$ \\
\hline STM0012 & Chaperone protein dnaK (Heat shock protein 70) & dnak & 69.2 & 4.84 & $22 \%$ \\
\hline STM0013 & Chaperone protein dnaJ & dnaJ & 41.31 & 8.41 & $25 \%$ \\
\hline STM0093 & Organic solvent tolerance protein & Imp & 89.8 & 5.21 & $23 \%$ \\
\hline STM0102 & $\mathrm{L}$-arabinose isomerase & $\operatorname{araA}$ & 55.89 & 5.88 & $23 \%$ \\
\hline STM0158 & Aconitate hydratase 2 & $\mathrm{acnB}$ & 82.2 & 5.35 & $29 \%$ \\
\hline STM0217 & Elongation factor Ts & tsf & 33.18 & 5.16 & $41 \%$ \\
\hline STM0316 & Aminoacyl-histidine dipeptidase & pepD & 52.69 & 5.17 & $15 \%$ \\
\hline STM0432 & Phosphonoacetaldehyde hydrolase & phnX & 28.57 & 5.58 & $41 \%$ \\
\hline STM0435 & Nucleotide-binding protein & yajQ & 18.31 & 5.6 & $52 \%$ \\
\hline STM0447 & Trigger factor & tig & 48.02 & 4.84 & $23 \%$ \\
\hline STM0488 & Adenylate kinase & $\mathrm{adk}$ & 23.49 & 5.53 & $51 \%$ \\
\hline STM0536 & Peptidyl-prolyl cis-trans isomerase $B$ & ppiB & 18.13 & 5.52 & $45 \%$ \\
\hline STM0608 & Chain T, crystal structure of Ahpc & ahpC & 20.64 & 5.03 & $24 \%$ \\
\hline STM0730 & Citrate synthase & gltA & 48.11 & 6.35 & $24 \%$ \\
\hline STM0772 & Phosphoglyceromutase & gpmA & 28.48 & 5.78 & $19 \%$ \\
\hline STM0776 & UDP-galactose 4-epimerase & galE & 37.28 & 5.79 & $31 \%$ \\
\hline STM0781 & Molybdate transporter periplasmic protein & $\bmod A$ & 27.5 & 6.53 & $67 \%$ \\
\hline STM0794 & Biotin synthase & bioB & 38.8 & 5.42 & $53 \%$ \\
\hline STM0830 & Glutamine-binding periplasmic protein precursor & $\mathrm{glnH}$ & 27.23 & 8.74 & $67 \%$ \\
\hline STM0877 & Putrescine-binding periplasmic protein precursor & potF & 41 & 6.02 & $35 \%$ \\
\hline STM0999 & Outer membrane protein $\mathrm{F}$ precursor & ompF & 40.05 & 4.73 & $28 \%$ \\
\hline STM1091 & Secretory Effector Protein & SopB & 61.93 & 9.27 & $42 \%$ \\
\hline STM1220 & $\mathrm{N}$-acetyl-D-glucosamine kinase & nagK & 33.06 & 5.09 & $29 \%$ \\
\hline STM1231 & DNA-binding response regulator in PhoQ system & phoP & 25.61 & 5.28 & $33 \%$ \\
\hline STM1290 & Glyceraldehyde-3-phosphate dehydrogenase & gapA & 36.1 & 6.33 & $29 \%$ \\
\hline STM1296 & Putative oxidoreductase & $y \operatorname{dj} A$ & 20.13 & 6.75 & $29 \%$ \\
\hline STM1302 & Exonuclease III & $x \operatorname{thA}$ & 30.79 & 6.19 & $23 \%$ \\
\hline STM1303 & Succinylornithine transaminase & astC & 43.72 & 6.13 & $34 \%$ \\
\hline STM1310 & NAD synthetase & nadE & 30.57 & 5.36 & $27 \%$ \\
\hline STM1378 & Pyruvate kinase I & pykF & 50.66 & 5.66 & $31 \%$ \\
\hline STM1431 & Superoxide dismutase & sodB & 21.35 & 5.58 & $35 \%$ \\
\hline STM1544 & PhoPQ-regulated protein & pqaA & 59.27 & 6.87 & $20 \%$ \\
\hline STM1567 & Alcohol dehydrogenase & adhP & 35.49 & 5.8 & $42 \%$ \\
\hline STM1589 & Putative NADP-dependent oxidoreductase & yncB & 39.2 & 5.6 & $23 \%$ \\
\hline STM1641 & ATP-dependent helicase & hrpA & 148.71 & 8.22 & $15 \%$ \\
\hline STM1661 & Putative universal stress protein & $y d a A$ & 35.62 & 5.17 & $66 \%$ \\
\hline STM1682 & Thiol peroxidase & $\operatorname{tpx}$ & 18.19 & 4.93 & $54 \%$ \\
\hline STM1714 & DNA topoisomerase I & topA & 97.03 & 8.56 & $26 \%$ \\
\hline STM1727 & Tryptophan synthase & $\operatorname{trpA}$ & 28.65 & 5.28 & $20 \%$ \\
\hline STM1746.S & Chain A, structural basis of multispecificity in Oppa & oppA & 58.77 & 5.85 & $29 \%$ \\
\hline STM1796 & Trehalase, periplasmic & treA & 63.6 & 5.19 & $63 \%$ \\
\hline
\end{tabular}


Table 1: MALDI-ToF analysis and identification of SE2472 proteins. (Continued)

\begin{tabular}{|c|c|c|c|c|c|}
\hline STM1886 & Glucose-6-phosphate 1-dehydrogenase & $z w f$ & 55.92 & 5.52 & $26 \%$ \\
\hline STM1923 & Chemotaxis protein motA & $\operatorname{mot} A$ & 32.08 & 5.47 & $31 \%$ \\
\hline STM1954 & Cystine-binding periplasmic protein precursor & fliY & 28.79 & 8.81 & $23 \%$ \\
\hline STM1959 & Flagellin & flic & 51.62 & 4.79 & $56 \%$ \\
\hline STM2104 & Phosphomannomutase in colanic acid gene cluster & cpsG & 50.02 & 5.18 & $20 \%$ \\
\hline STM2167 & $\mathrm{NADH}$ independent D-lactate dehydrogenase & dld & 65.05 & 6.47 & $31 \%$ \\
\hline STM2190 & D-galactose binding periplasmic protein & $\mathrm{mglB}$ & 35.81 & 5.81 & $31 \%$ \\
\hline STM2203 & Endonuclease IV & nfo & 31.2 & 5.17 & $45 \%$ \\
\hline STM2205 & Fructose-1-phosphate kinase & fruK & 33.71 & 5.36 & $39 \%$ \\
\hline STM2282 & Glycerophosphodiester phosphodiesterase & glpQ & 40.42 & 5.66 & $24 \%$ \\
\hline STM2337 & Acetate kinase & ackA & 43.26 & 5.93 & $21 \%$ \\
\hline STM2347 & Putative phosphoesterase & $y f c E$ & 19.91 & 5.93 & $43 \%$ \\
\hline STM2362 & Amidophosphoribosyltransferase & purF & 56.56 & 5.51 & $23 \%$ \\
\hline STM2501 & Polyphosphate kinase & ppk & 80.46 & 8.7 & $30 \%$ \\
\hline STM2549 & Anaerobic sulfide reductase & asrB & 30.61 & 6.24 & $28 \%$ \\
\hline STM2647 & Uracil-DNA glycosylase & ung & 25.48 & 6.56 & $67 \%$ \\
\hline STM2829 & DNA strand exchange and recombinant protein & recA & 37.94 & 5.08 & $28 \%$ \\
\hline STM2864 & Iron transporter protein, fur regulated & sitD & 33.7 & 7.84 & $41 \%$ \\
\hline STM2882 & Secretory Effector Protein & sipA & 73.94 & 6.41 & $35 \%$ \\
\hline STM2884 & Translocation Machinery Component & $\operatorname{sipC}$ & 42.98 & 8.88 & $38 \%$ \\
\hline STM2924 & RNA polymerase sigma factor $r p o S$ & rpos & 37.93 & 4.86 & $29 \%$ \\
\hline STM2952 & Enolase & eno & 36.24 & 5.13 & $30 \%$ \\
\hline STM2976 & L-fucose isomerase & fucl & 64.77 & 5.6 & $31 \%$ \\
\hline STM2993 & Exonuclease V, alpha chain & recD & 67.05 & 8.02 & $36 \%$ \\
\hline STM3068 & Fructose-bisphosphate aldolase & fba & 39.3 & 5.68 & $25 \%$ \\
\hline STM3069 & Phosphoglycerate kinase & pgk & 41.28 & 5.09 & $38 \%$ \\
\hline STM3186 & Outer membrane channel protein & tolC & 53.39 & 5.42 & $31 \%$ \\
\hline STM3219 & 2,4-dieonyl-CoA reductase & $\mathrm{fadH}$ & 73.13 & 6.55 & $35 \%$ \\
\hline STM3225 & Serine/threonine transporter & sstT & 43.41 & 8.43 & $33 \%$ \\
\hline STM3294 & Phosphoglucosamine mutase & glmM & 47.44 & 5.74 & $32 \%$ \\
\hline STM3342 & Stringent starvation protein A & $\operatorname{sspA}$ & 32.05 & 5.22 & $19 \%$ \\
\hline STM3359 & Malate dehydrogenase & mdh & 32.63 & 6.01 & $22 \%$ \\
\hline STM3380 & Acetyl CoA carboxylase & accC & 49.26 & 6.52 & $28 \%$ \\
\hline STM3401 & Shikimate dehydrogenase & aroE & 29.29 & 5.73 & $51 \%$ \\
\hline STM3445 & Elongation factor Tu & tuf & 43.26 & 5.3 & $32 \%$ \\
\hline STM3446 & Elongation factor $\mathrm{G}$ & fusA & 77.72 & 5.17 & $23 \%$ \\
\hline STM3484 & DNA adenine methylase & dam & 32.03 & 8.93 & $26 \%$ \\
\hline STM3496 & Putative hydrolase & yrfG & 72.4 & 5.23 & $19 \%$ \\
\hline STM3500 & Phosphoenolpyruvate carboxykinase & pckA & 59.9 & 5.67 & $28 \%$ \\
\hline STM3502 & Osmolarity response regulator & ompR & 27.35 & 6.04 & $31 \%$ \\
\hline STM3557 & Glycerol-3-phosphatase transporter binding protein & ugpB & 48.49 & 6.97 & $15 \%$ \\
\hline STM3612 & 2-dehydro-3-deoxygluconokinase & kdgK & 34.35 & 5.01 & $17 \%$ \\
\hline STM3884 & D-ribose periplasmic binding protein & $\mathrm{rbsB}$ & 30.9 & 8.54 & $38 \%$ \\
\hline STM3968 & Uridine phosphorylase & udp & 27.38 & 6.32 & $34 \%$ \\
\hline STM3997 & Thiol:disulfide interchange protein & dsbA & 22.9 & 6.3 & $54 \%$ \\
\hline STM4029 & Putative acetyltransferase & yiiD & 36.92 & 6.08 & $34 \%$ \\
\hline
\end{tabular}


Table 1: MALDI-ToF analysis and identification of SE2472 proteins. (Continued)

\begin{tabular}{|c|c|c|c|c|c|}
\hline STM4166 & NADH pyrophosphatase & nudC & 29.62 & 5.89 & $48 \%$ \\
\hline STM4256 & Single-strand DNA-binding protein & ssb & 19.06 & 5.46 & $34 \%$ \\
\hline STM4329 & Co-chaperonin groES & groES & 10.19 & 5.36 & $56 \%$ \\
\hline STM4330 & Chaperonin groEL & groEL & 57.16 & 4.85 & $38 \%$ \\
\hline STM4343 & Fumarate reductase & $\operatorname{frd} A$ & 65.49 & 5.95 & $19 \%$ \\
\hline STM4359 & DNA mismatch repair protein mutL & mutL & 67.76 & 6.51 & $21 \%$ \\
\hline STM4414 & Inorganic pyrophosphatase & ppa & 19.68 & 5.01 & $43 \%$ \\
\hline STM4513 & Putative permease & yjiG & 16.12 & 7.76 & $61 \%$ \\
\hline STM4567 & Deoxyribose-phosphate aldolase & deoC & 27.68 & 5.87 & $47 \%$ \\
\hline STM4568 & Thymidine phosphorylase & deoA & 47 & 4.96 & $38 \%$ \\
\hline STM4569 & Phosphopentomutase & deoB & 44.24 & 5.15 & $52 \%$ \\
\hline STM4598 & Two-component response regulator & $\operatorname{arcA}$ & 45.56 & 5.47 & $58 \%$ \\
\hline STY2300 & CDP-6-deoxy-D-xylo-4-hexulose-3-dehydrase & $\mathrm{rfbH}$ & 48.1 & 5.27 & $46 \%$ \\
\hline STY2300 & CDP-4-keto-6-deoxy-D-glucose-3-dehydrase & ddhC & 48.2 & 5.35 & $39 \%$ \\
\hline
\end{tabular}

broth in the absence and presence of $\mathrm{H} 2 \mathrm{O} 2$. Western blot analyses were used to determine the expression of the tagged proteins with an anti-FLAG antibody (Figure 5B, top panel). The expression of bacterial FliC protein, which was not significantly altered in the presence of 5 $\mathrm{mM} \mathrm{H} 2 \mathrm{O} 2$ (Table 2), was used as the internal control (Figure 5B, lower panel). Normalization of samples was also carried out by loading total proteins extracted from the same CFU (e.g. $5 \times 107$ CFU) of bacteria in each lane. Consistent with the results from our proteomic analyses (Table 2 and 3), the levels of SipC and SopB were about 3fold higher and 2-fold lower in the presence of $\mathrm{H} 2 \mathrm{O} 2$, respectively, while no change in the expression of SipA was detected (Figure 5B-C).

\section{Differential expression of SPI-1 factors in cultured macrophages and the spleen of infected animals}

Immunodetection of the SPI-1 proteins in cultured media in the absence and presence of $\mathrm{H}_{2} \mathrm{O}_{2}$ validated the proteomic observations. To evaluate the presence of these proteins in an environment more relevant to infection, the tagged Salmonella strains were used to infect macrophages and mice, and the expression of the tagged proteins was determined by immunodetection at different time points following infection. The expression of the tagged proteins in the bacterial strains isolated from the macrophages and the spleen of infected mice was detected using Western blot analysis with an anti-FLAG antibody and normalized using the expression of bacterial protein DnaK as the internal control (Figure 6A-B). Normalization of protein samples was also carried out by loading total proteins extracted from the same CFU (e.g. $5 \times 10^{7} \mathrm{CFU}$ ) of bacteria in each lane. The protein level of DnaK did not appear to be significantly different in bacteria recovered from macrophages [26], and from the spleen of infected animals as similar amount of the DnaK protein was detected from $5 \times 10^{7} \mathrm{CFU}$ of each bacterial strain regardless of infection route (intraperitoneally or intragastrically) or time point postinfection (12-24 hours or 5-7 days)[16](data not shown).

In cultured macrophages, SipA, SipC, and SopB were all expressed at the early phase (e.g. $0.2 \mathrm{~h}$ ) of infections. However, by $5 \mathrm{hr}$ post infection, the levels of the three SPI-1 proteins diverged, with the SipC level increased, the SopB level decreased while SipA level remained unchanged (Figure 6A and 6C). To determine the relative abundance of these proteins in the spleen during systemic infection, BALB/c mice were infected intraperitoneally. Salmonella was recovered from the spleen at different time points postinfection, and the expression levels of the tagged proteins were determined. Similar to the results of macrophage infection, all three proteins were detected during the early stage of infection (i.e. 0.5 days). However, at a later stage of systemic infection (i.e. 5 days), the level of SipC increased and the level of SopB decreased while the level of SipA remained unchanged (Figure 6B and 6D). These results correlated with those observed in the proteomic analyses and in the macrophage experiments. Furthermore, these data strongly suggest that different SPI-1 factors are specifically expressed at late stage of Salmonella infection, and highlight a possible role of SipC in late phase of macrophage and in vivo infections of Salmonella.

\section{Discussion}

Stable isotope labeling procedure coupled with MS-based analysis for quantitative proteomic study of bacterial protein expression

In the postgenomic era, new methodologies are needed that can quantitatively, globally, and accurately measure 
protein expression in cells and tissues [37]. In this study, we have modified the SILAC method to develop a stable isotope labeling procedure coupled with MS analysis to carry out quantitative proteomic analysis of Salmonella. As a "proof of principle" pilot study, a total of 103 SE2472 proteins were monitored for their expression profiles upon exposure to $\mathrm{H}_{2} \mathrm{O}_{2}$.

At least seventy six proteins have been found to be modulated in the presence of $\mathrm{H}_{2} \mathrm{O}_{2}$. For example, the expression of SPI-1 proteins SipC and SopB was found to be differentially regulated in the presence of $\mathrm{H}_{2} \mathrm{O}_{2}$, while the expression of SipA remained unchanged. The level of SipC increased with $\mathrm{H}_{2} \mathrm{O}_{2}$ exposure, and the level of SopB decreased. These results were confirmed using Western blot analyses of protein expressions from FLAG-tagged Salmonella strains incubated with $\mathrm{H}_{2} \mathrm{O}_{2}$, validating the accuracy and reproducibility of our system for quantitative analyses of protein expression.

\section{Modulation of Salmonella protein expressions upon exposure to oxidative stress}

Many Salmonella proteins we analyzed showed a moderate amount of up-regulation upon exposure to oxidative stress (Table 2 and 3), consistent with earlier studies involving E. coli's response to oxidative stress [9-11,38]. For example, RecA (DNA strand exchange and recombinant protein) has been shown to be induced along with members of heat shock proteins [39]. The expression of superoxide dismutase SodB, which is a part of the SoxRS system $[6,7,9]$, increased by $110 \%$. When categorized by protein functions, we observed several patterns (Table 3). First, many enzymes involved in glycolysis and the TCA cycle were upregulated, showing up to a $330 \%$ increase. Consistent with the increase in general metabolism, amino acid biosynthesis was also affected in a positive fashion. Considering that intermediates from the glycolytic pathway are used in amino acid biosynthesis, the overall upregulation in downstream pathways is expected. This is consistent with our previous observations that amino acid supplementation increased the resistance of $E$. coli to $\mathrm{H}_{2} \mathrm{O}_{2}$ [38]. Interestingly, the pentose phosphate pathway was relatively unaffected in the presence of $\mathrm{H}_{2} \mathrm{O}_{2}$. Since one of the primary functions of the pathway is to generate ribose-5-phosphate for the synthesis of nucleotides and nucleic acids, other enzymes involved in nucleotide biosynthesis should show little change either. As expected, three such enzymes detected in this study (i.e. amidophosphoribosyltransferase, thymidine phosphorylase, and uridine phosphorylase) showed a varied response, ranging from a minor upregulation to a downregulation (Table 3). Further investigation of additional enzymes involved in the process should reveal the nature of this response.
We have noted that different proteins within the same operon may exhibit different expression levels in our results. Differential expression of proteins within the same operon has been reported [40] and may represent a regulatory mechanism for the expression of functional protein complexes. We have also noted that in some instances one protein was detected while another within the same operon was not. For example, redundant hydrogen peroxide scavenger systems have been reported to be present in Salmonella [41]. In our results, AhpC was not regulated while the other scavengers (KatE, KatG, KatN and TsaA) were not detected. One of the reasons for the divergence from expected protein level could be the limitation of the methodology we used in the study.

We used two-dimensional (2-D) gel electrohphoresis coupled with peptide fingerprinting by mass spectrometry which allowed us to perform global protein profiling quantitatively. However, our methodology is limited to proteins that can be detected by 2-D gel electrophoresis and identified by peptide fingerprinting. Proteins with low abundance or could not be identified by peptide fingerprinting for various reasons (e. g. post-translational modifications, resistance to trypsin digestion, or poor ionization of peptides) were not included in our analysis. Thus, our study by no means encompasses all the possible proteins expressed by SE2472 and we are presenting only the proteins we were able to successfully identify by peptide fingerprinting with high confidence in all three independent experiments. The absence of a protein in our results does not necessarily mean it was not expressed and/or induced; instead its expression status is yet to be determined. Our results are consistent with the notion that current proteomic approaches, including liquid chromatography mass spectrometry (LC-MS) and MALDI-ToF procedures, do not have the capacity to detect the entire proteomes of Salmonella [25-28]. Each approach has been shown to detect a distinct set of Salmonella proteins that exhibited limited overlap of protein coverage, and these complementary approaches should be carried out independently to generate a complete and full coverage of bacterial proteomes.

\section{Expression of SPI-1 proteins in post-invasion and late phase of Salmonella infection}

Our proteomic results on SPI-1 proteins SipA, SipC, and SopB suggest that the expression of these proteins may be differentially modulated during infection under biologically relevant environments that resemble the oxidative stress condition. Efficient expression of SipA at late stage of infection in macrophages and in the spleen, as shown in our results, has been observed in Salmonella enterica serovar Typhimurium $[15,16]$. This is consistent with its functions in modulating actin dynamics and bacterial localization in infected macrophages [42-44] and in 
Table 2: Quantitative analysis of the expression of SE2472 proteins upon exposure to $\mathrm{H}_{2} \mathrm{O}_{2}$.

\begin{tabular}{|c|c|c|c|}
\hline Locus Tag & Description & Gene & \% Change \\
\hline PSLT011 & $\operatorname{Dlp}(\operatorname{SrgA})$ & $\operatorname{srgA}$ & $12 \pm 2 \%$ \\
\hline STM0007 & Transaldolase B & talB & $0 \%$ \\
\hline STM0012 & Chaperone protein dnaK (Heat shock protein 70) & dnaK & $56 \pm 7 \%$ \\
\hline STM0013 & Chaperone protein dnaJ & dnaJ & $38 \pm 3 \%$ \\
\hline STM0093 & Organic solvent tolerance protein & $\operatorname{Imp}$ & $210 \pm 30 \%$ \\
\hline STM0102 & L-arabinose isomerase & $\operatorname{araA}$ & $26 \pm 2 \%$ \\
\hline STM0158 & Bifunctional aconitate hydratase & $\mathrm{acnB}$ & $25 \pm 5 \%$ \\
\hline STM0217 & Elongation factor Ts & tsf & $21 \pm 4 \%$ \\
\hline STM0316 & Aminoacyl-histidine dipeptidase & pepD & $9 \pm 1 \%$ \\
\hline STM0432 & Phosphonoacetaldehyde hydrolase & phnX & $31 \pm 3 \%$ \\
\hline STM0435 & Nucleotide-binding protein & yajQ & $0 \%$ \\
\hline STM0447 & Trigger factor & tig & $11 \pm 2 \%$ \\
\hline STM0488 & Adenylate kinase & adk & $0 \%$ \\
\hline STM0536 & Peptidyl-prolyl cis-trans isomerase B & ppiB & $0 \%$ \\
\hline STM0608 & Chain T, crystal structure of Ahpc & ahpC & $0 \%$ \\
\hline STM0730 & Citrate synthase & gltA & $42 \pm 5 \%$ \\
\hline STM0772 & Phosphoglyceromutase & gpmA & $-40 \pm 10 \%$ \\
\hline STM0776 & UDP-galactose 4-epimerase & galE & $23 \pm 2 \%$ \\
\hline STM0781 & Molybdate transporter periplasmic protein & $\bmod A$ & $11 \pm 2 \%$ \\
\hline STM0794 & Biotin synthase & bioB & $0 \%$ \\
\hline STM0830 & Glutamine-binding periplasmic protein precursor & glnH & $10 \pm 3 \%$ \\
\hline STM0877 & Putrescine-binding periplasmic protein precursor & potF & $11 \pm 2 \%$ \\
\hline STM0999 & Outer membrane protein $\mathrm{F}$ precursor & ompF & $0 \%$ \\
\hline STM1091 & Secretory Effector Protein & SopB & $-55 \% \pm 7 \%$ \\
\hline STM1220 & $\mathrm{N}$-acetyl-D-glucosamine kinase & nagK & $12 \pm 3 \%$ \\
\hline STM1231 & DNA-binding response regulator in $\mathrm{PhoQ}$ system & phoP & $20 \pm 6 \%$ \\
\hline STM1290 & Glyceraldehyde-3-phosphate dehydrogenase & gapA & $31 \pm 3 \%$ \\
\hline STM1296 & Putative oxidoreductase & $y \operatorname{dj} A$ & $-30 \pm 5 \%$ \\
\hline STM1302 & Exonuclease III & $x \operatorname{th} A$ & $0 \%$ \\
\hline STM1303 & Succinylornithine transaminase & astC & $41 \pm 7 \%$ \\
\hline STM1310 & NAD synthetase & nadE & $9 \pm 1 \%$ \\
\hline STM1378 & Pyruvate kinase I & pykF & $87 \pm 12 \%$ \\
\hline STM1431 & Superoxide dismutase & sodB & $110 \pm 20 \%$ \\
\hline STM1544 & PhoPQ-regulated protein & pqaA & $19 \pm 2 \%$ \\
\hline STM1567 & Alcohol dehydrogenase & $\operatorname{adhP}$ & $9 \pm 2 \%$ \\
\hline STM1589 & Putative NADP-dependent oxidoreductase & yncB & $12 \pm 2 \%$ \\
\hline STM1641 & ATP-dependent helicase & hrpA & $20 \pm 3 \%$ \\
\hline STM1661 & Putative universal stress protein & ydaA & $140 \pm 20 \%$ \\
\hline STM1682 & Probable peroxidase & $\operatorname{tpx}$ & $19 \pm 2 \%$ \\
\hline STM1714 & DNA topoisomerase I & topA & $17 \pm 4 \%$ \\
\hline STM1727 & Tryptophan synthase & $\operatorname{trpA}$ & $37 \pm 9 \%$ \\
\hline STM1746.S & Chain A, structural basis of multispecificity in Oppa & oppA & $0 \%$ \\
\hline STM1796 & Trehalase, periplasmic & treA & $25 \pm 3 \%$ \\
\hline STM1886 & Glucose-6-phosphate 1-dehydrogenase & $z w f$ & $0 \%$ \\
\hline
\end{tabular}


Table 2: Quantitative analysis of the expression of SE2472 proteins upon exposure to $\mathrm{H}_{2} \mathrm{O}_{2}$. (Continued)

\begin{tabular}{|c|c|c|c|}
\hline STM1923 & Chemotaxis protein mot $A$ & motA & $14 \pm 3 \%$ \\
\hline STM1954 & Cystine-binding periplasmic protein precursor & fliY & $9 \pm 2 \%$ \\
\hline STM1959 & Flagellin & flic & $0 \%$ \\
\hline STM2104 & Phosphomannomutase in colanic acid gene cluster & cpsG & $23 \pm 6 \%$ \\
\hline STM2167 & NADH independent D-lactate dehydrogenase & dld & $16 \pm 5 \%$ \\
\hline STM2190 & D-galactose binding periplasmic protein & $\mathrm{mglB}$ & $34 \pm 3 \%$ \\
\hline STM2203 & Endonuclease IV & nfo & $0 \%$ \\
\hline STM2205 & Fructose-1-phosphate kinase & fruk & $35 \pm 3 \%$ \\
\hline STM2282 & Glycerophosphodiester phosphodiesterase & glpQ & $15 \pm 3 \%$ \\
\hline STM2337 & Acetate kinase & ackA & $23 \pm 3 \%$ \\
\hline STM2347 & Putative phosphoesterase & $y f c E$ & $0 \%$ \\
\hline STM2362 & Amidophosphoribosyltransferase & purF & $10 \pm 4 \%$ \\
\hline STM2501 & Polyphosphate kinase & ppk & $7 \pm 3 \%$ \\
\hline STM2549 & Anaerobic sulfide reductase & asrB & $0 \%$ \\
\hline STM2647 & Uracil-DNA glycosylase & ung & $27 \pm 2 \%$ \\
\hline STM2829 & DNA strand exchange and recombinant protein & recA & $24 \pm 2 \%$ \\
\hline STM2864 & Iron transporter protein, fur regulated & sitD & $-45 \pm 8 \%$ \\
\hline STM2882 & Secretory Effector Protein & $\operatorname{sip} A$ & $0 \%$ \\
\hline STM2884 & Translocation Machinery Component & $\operatorname{sipC}$ & $301 \pm 30 \%$ \\
\hline STM2924 & RNA polymerase sigma factor $r p o S$ & rpos & $13 \pm 2 \%$ \\
\hline STM2952 & Enolase & eno & $23 \pm 4 \%$ \\
\hline STM2976 & L-fucose isomerase & fucl & $0 \%$ \\
\hline STM2993 & Exonuclease $V$, alpha chain & recD & $0 \%$ \\
\hline STM3068 & Fructose-bisphosphate aldolase & fba & $52 \pm 7 \%$ \\
\hline STM3069 & Phosphoglycerate kinase & pgk & $20 \pm 3 \%$ \\
\hline STM3186 & Outer membrane channel protein & tolC & $0 \%$ \\
\hline STM3219 & 2,4-dieonyl-CoA reductase & $\mathrm{fadH}$ & $24 \pm 3 \%$ \\
\hline STM3225 & Serine/threonine transporter & sstT & $23 \pm 3 \%$ \\
\hline STM3294 & Phosphoglucosamine mutase & glmM & $18 \pm 2 \%$ \\
\hline STM3342 & Stringent starvation protein $\mathrm{A}$ & $\operatorname{sspA}$ & $-20 \pm 4 \%$ \\
\hline STM3359 & Malate dehydrogenase & mdh & $36 \pm 6 \%$ \\
\hline STM3380 & Acetyl CoA carboxylase & accC & $11 \pm 2 \%$ \\
\hline STM3401 & Shikimate dehydrogenase & aroE & $12 \pm 3 \%$ \\
\hline STM3445 & Elongation factor Tu & tuf & $0 \%$ \\
\hline STM3446 & Elongation factor $\mathrm{G}$ & fusA & $9 \pm 2 \%$ \\
\hline STM3484 & DNA adenine methylase & dam & $26 \pm 3 \%$ \\
\hline STM3496 & Putative hydrolase & yrfG & $0 \%$ \\
\hline STM3500 & Phosphoenolpyruvate carboxykinase & pckA & $330 \pm 40 \%$ \\
\hline STM3502 & Osmolarity response regulator & ompR & $12 \pm 3 \%$ \\
\hline STM3557 & Glycerol-3-phosphatase transporter binding protein & ugpB & $0 \%$ \\
\hline STM3612 & 2-dehydro-3-deoxygluconokinase & kdgK & $9 \pm 2 \%$ \\
\hline STM3884 & D-ribose periplasmic binding protein & rbsB & $31 \pm 3 \%$ \\
\hline STM3968 & Uridine phosphorylase & udp & $11 \pm 5 \%$ \\
\hline STM3997 & Thiol:disulfide interchange protein & $\mathrm{dsbA}$ & $10 \pm 5 \%$ \\
\hline STM4029 & Putative acetyltransferase & yiiD & $0 \%$ \\
\hline
\end{tabular}


Table 2: Quantitative analysis of the expression of SE2472 proteins upon exposure to $\mathrm{H}_{2} \mathrm{O}_{2}$. (Continued)

\begin{tabular}{llcc}
\hline STM4166 & NADH pyrophosphatase & nudC & $10 \pm 2 \%$ \\
STM4256 & Single-strand DNA-binding protein & ssb & $19 \pm 2 \%$ \\
STM4329 & Co-chaperonin groES & groES & $51 \pm 3 \%$ \\
STM4330 & Chaperonin groEL & groEL & $43 \pm 2 \%$ \\
STM4343 & Fumarate reductase & frdA & $40 \pm 2 \%$ \\
STM4359 & DNA mismatch repair protein mutL & mutL & $41 \pm 3 \%$ \\
STM4414 & Inorganic pyrophosphatase & ppa & $0 \%$ \\
STM4513 & Putative permease & yjiG & $-78 \pm 15 \%$ \\
STM4567 & Deoxyribose-phosphate aldolase & deoC & $0 \%$ \\
STM4568 & Thymidine phosphorylase & deoA & $-9 \pm 2 \%$ \\
STM4569 & Phosphopentomutase & deoB & $0 \%$ \\
STM4598 & Two-component response regulator & arcA & $10 \pm 4 \%$ \\
STY2300 & CDP-6-deoxy-D-xylo-4-hexulose-3-dehydrase & rfbH & ddhC \\
STY2300 & CDP-4-keto-6-deoxy-D-glucose-3-dehydrase & $0 \%$ & $0 \%$
\end{tabular}

Relative expression level in the presence of $\mathrm{H}_{2} \mathrm{O}_{2}$ compared against control (in the absence of $\mathrm{H}_{2} \mathrm{O}_{2}$ ) is shown. An average of 10 peaks was used to calculate the mean intensity ratios and the error percentage of each protein spot. The results were the average from triplicate experiments. The limit of detection was arbitrarily set to $5 \%$ and any proteins that showed less than $5 \%$ change were classified as $0 \%$.

inducing inflammatory response for supporting Salmonella infection $[45,46]$.

Our results of SopB protein expression are consistent with recent proteomic analysis results that Salmonella enterica serovar Typhimurium (strain 14028) reduced SopB protein expression by more than 2-fold within 4 hours of infection of RAW264.7-like macrophages [47]. SopB encodes a phosphoinositide phosphatase and is a multifunctional protein important for bacterial infection [48]. It facilitates bacterial invasion by inducing membrane ruffling and modulating actin polymerization [4951], and stimulates inducible nitric oxide synthase (iNOS) production long after invasion and participates in the formation of the Salmonella-containing vacuole in macrophages [52-54]. Recently, SopB has been shown to carry

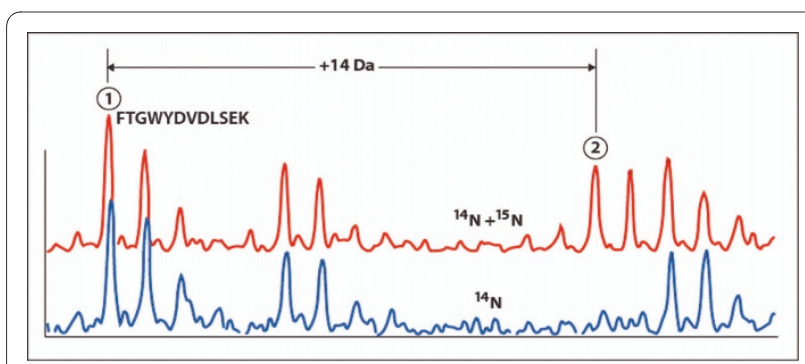

Figure 4 Quantitation of proteins by their tryptic peptide fragments. A tryptic peptide fragment FTGWYDVDLSEK (MW 1459.81) from S. Enteritidis phosphoglyceromutase was analyzed for the level of downregulation. A peak at $\mathrm{m} / \mathrm{z} 1473$ represents ${ }^{15} \mathrm{~N}$-labeled population (upper spectrum), which does not appear in the unlabeled population. The ratio of two peak intensities ( 27 and 17 , respectively) represents a relative protein expression level of 0.6 , or a $40 \%$ downregulation. out its diverse functions by localizing to different cellular compartments in a ubiquitin-dependent manner [48]. The reduced expression of SopB in the presence of $\mathrm{H}_{2} \mathrm{O}_{2}$ and at later time points of infection in macrophages and in the spleen in our study is consistent with the notion that SopB negatively regulates expression of sorting nexin 6 (SNX6), a protein involved in intracellular transport [47].

Our results also provide the first direct evidence that $\mathrm{SipC}$ is expressed in the spleen at late stages of Salmonella enterica serovar Enteritidis infection in mice. SipC is a Salmonella invasion protein (Sip) that is central for the initiation of the bacterial entry process. SipC and SipB form an extracellular complex following their secretion through the SPI-1 T3SS, and they are thought to assemble into a plasma membrane-integral structure (translocon) that mediates effector delivery [55-57]. Furthermore, SipC has been reported to promote actin nucleation and contribute to Salmonella-induced inflammation [58]. While the expression of SipC has been studied in vitro, its expression in the spleen has not been extensively investigated. The induced expression of SipC in Salmonella in the presence of oxidative stress and at late stages of infection in macrophages and in the spleen suggests that the level of this protein is highly regulated in vivo and that appropriate level of expression may contribute to the pathogenesis of Salmonella. This is consistent with recent observations that the translocase activity of $\mathrm{SipC}$ is important for the delivery of effector proteins and attachment of Salmonella to non-phagocytic cells; however, in the context of systemic infection, its actin-binding activity may facilitate bacterial infection of 
phagocytes $[5,58,59]$. Thus, examination of the expression of SipC and other SPI-1 factors both in vitro and in vivo in the context of infection, as reported in our study, is crucial to ultimately understand the actual functions and actions of these factors.

Using a different quantitative proteomic analysis approach without stable isotope labeling, Smith and coworkers have recently reported the protein expression of Salmonella enterica serovars Typhimurium and Typhi that grew in different culture conditions (e.g. stationary, $\log$, and phagosome-mimicking conditions) and in macrophages [25-28]. Proteomic analysis of Salmonella protein expression in the spleen of infected animals has also been reported [24]. In these studies, the protein expression of the S. Typhimurium homologs of many of the oxidative stress-responsive proteins identified in our study were found to be modulated under phagosome-mimicking conditions and in macrophages, further validating our analysis as an accurate and reproducible approach for quantitative proteomic analysis. Some of our protein expression results may not be consistent with those of messenger RNA expression that have been recently published [19-23] as the expression of many Salmonella genes is tightly controlled both transcriptionally and post-transcriptionally $[18,60]$. Our results of protein expression in vivo may not necessarily correlate with the previous observations in vitro because of the different environments Salmonella was exposed to. The difference between our results and previously published reports may also be due to the difference in the serovars and strains used for the studies, and the coverage of the proteins due to different methodologies used for the studies [25-28,33]. None of these previous studies has reported the differential expression of SipA, SipC, and SopB in hydrogen peroxide-treated Salmonella, as described in our study. Our results complemented and further extended previous proteomic analysis of Salmonella, and furthermore, demonstrated the importance of examining the expression of Salmonella proteins, including SPI-1 proteins, in vitro using different quantitative proteomic analyses and in vivo in the context of infection.

Each of the currently-available proteomic approaches, including LC-MS and MALDI-ToF procedures, can only detect a subset of Salmonella proteins and may exhibit limited overlap of protein coverage with other methods [25-28]. It is suggested that these complementary approaches should be carried out independently to generate a comprehensive coverage of bacterial proteomes. Further investigation with our quantitative proteomic approach, in combination with examination and confirmation of the expression of these proteins in vivo, should provide significant insights into the role of these proteins in pathogenesis during Salmonella infection.

\section{Conclusion}

We have employed stable isotope labeling coupled with mass spectrometry to carry out a quantitative proteomic analysis of Salmonella enterica serovar Enteritidis. Seventy-six proteins whose expression is differentially modulated upon exposure to $\mathrm{H}_{2} \mathrm{O}_{2}$ have been identified. SPI-1 effector SipC was expressed approximately 3 -fold higher and SopB was expressed approximately 2 -fold lower in the presence of $\mathrm{H}_{2} \mathrm{O}_{2}$, while no significant change in the expression of another SPI-1 protein SipA was observed. The expression of these SPI-1 factors was confirmed by Western blot analyses, validating the accuracy and reproducibility of our approach for quantitative analyses of protein expression. Furthermore, substantial expression of SipA and SipC but not SopB was found in the late phase of infection in macrophages and in the spleen of infected mice. This study provides the first direct evidence that SipC is highly expressed in the spleen at late stage of salmonellosis in vivo. Our results also suggest a possible role of the identified proteins, including SipC, in supporting the survival and replication of Salmonella under oxidative stress and during its systemic infection in vivo.

\section{Methods}

Reagents and preparation of protein samples for proteomic analysis

All reagents were obtained from Sigma-Aldrich unless otherwise specified. Salmonella enterica serovar Enteritidis (clinical isolate SE2472) [33] was cultured in LB broth-like normal $\left({ }^{14} \mathrm{~N}\right)$ and ${ }^{15} \mathrm{~N}$-labeled media (Silantes GmbH, München, Germany), which are identical in chemical composition. The percentage of ${ }^{15} \mathrm{~N}$ in the labeled media is more than $98 \%$ (Silantes $\mathrm{GmbH}$, München, Germany). The cultures were inoculated with a starter culture grown in normal $\left({ }^{14} \mathrm{~N}\right)$ or ${ }^{15} \mathrm{~N}$-labeled media until mid-log phase. Two hundred fifty milliliter culture medium was inoculated with each starter culture and grown at $37^{\circ} \mathrm{C}$ with shaking at $225 \mathrm{rpm}$ for $4 \mathrm{~h} .{ }^{15} \mathrm{~N}$ labeled culture was treated with $5 \mathrm{mM} \mathrm{H}_{2} \mathrm{O}_{2}$, which is well below the minimal inhibition concentration (MIC) of SE2472 (20 mM), and both cultures were grown for $2 \mathrm{~h}$ following the addition of $\mathrm{H}_{2} \mathrm{O}_{2}$. Protein extraction was performed with $\mathrm{B}^{\mathrm{PER}}{ }^{\circ}$ bacterial protein extraction reagent (Thermo Fisher Scientific, Rockford, IL) and quantified with $\mathrm{D}_{\mathrm{c}}$ Protein Assay Kit (Bio-Rad, Hercules, CA), which has an error rate of $2.5 \%$ in our experiments. We took this error rate into consideration by classifying 
any protein that had a $5 \%$ change or less as unchanged (having a $0 \%$ change).

\section{Two-dimensional gel electrophoresis and visualization of bacterial proteins}

Protein samples were further solubilized in rehydration buffer (8 M urea, 2\% CHAPS, $50 \mathrm{mM}$ DTT, $0.2 \%$ BioLyte $3 / 10$ ampholytes [Bio-Rad, Hercules, CA] and trace amount of Bromophenol Blue). ReadyStrip ${ }^{\text {ma }}$ IPG strips (Bio-Rad, Hercules, CA) were loaded with $200 \mu \mathrm{g}$ of protein samples (either normal or 1:1 mixture of normal and ${ }^{15} \mathrm{~N}$-labeled samples) for preparative $2 \mathrm{D}$ gels, and allowed to rehydrate for 18-22 h. Isoelectric focusing (IEF) was performed at $20^{\circ} \mathrm{C}$ using PROTEAN ${ }^{\circ}$ IEF cell (Bio-Rad, Hercules, CA). A 3-step protocol (250 V-20 $\min / 8,000 \mathrm{~V}-2.5 \mathrm{~h} / 8,000 \mathrm{~V}-10,000 \mathrm{~V} . \mathrm{h})$ was used for the IEF procedure following manufacturer's recommendations (Bio-Rad, Hercules, CA).

After the IEF procedure, the IPG strips were reduced in Equilibration Buffer I (6 M urea, 2\% SDS, $0.375 \mathrm{M}$ Tris$\mathrm{HCl}$ [pH 8.8], 20\% glycerol, 2\% DTT) and alkylated in Equilibration Buffer II (6 M urea, 2\% SDS, 0.375 M Tris$\mathrm{HCl}$ [pH 8.8], 20\% glycerol, $0.25 \%$ iodoacetamide). Strips were loaded onto $8-16 \%$ Criterion $^{\text {Tm }}$ Tris-HCl SDS gel (Bio-Rad, Hercules, CA) and electrophoresed at $200 \mathrm{~V}$ for 65 min. Gels were visualized using Coomassie Brilliant Blue R-250 or silver staining (Invitrogen, Carlsbad, CA).

\section{Mass spectrometric identification of proteins}

Gels were scanned and protein spots of interest were excised using the Xcise automated gel processor (Proteome Systems, North Ryde, Australia). Gel spots were destained and washed, followed by in-gel tryptic digestion using proteomic grade trypsin (Sigma-Aldrich, St. Louis, MO). Peptide fragments were collected and purified using ZipTip $^{\text {tm }} \mathrm{C}_{18}$ reverse-phase prepacked resin (Millipore, Billerica, MA) and mixed with an equal volume of $10 \mathrm{mg} / \mathrm{ml} \alpha$-cyano-4-hydroxy-trans-cinnamic acid (Sigma-Aldrich, St. Louis, MO) in $0.1 \%$ trifluoroacetic acid (TFA) $/ 50 \%$ acetonitrile solution and directly spotted onto a stainless steel target plate for mass analysis. Axima-CFR ${ }^{\mathrm{mi}}$ Plus (Shimadzu Biotech, Columbia, MD) was used for MALDI-ToF MS analysis, and 50-100 profiles were obtained for each sample, ensuring sufficient peak data for database interrogation. Probabilitybased scoring method with MASCOT database search engine (Matrix Science, Boston, MA) was used to identify each protein, based on the likelihood of search results being a random match. We used the following parameters for our protein identification: Database: NCBINR, MASCOT value cut off: greater than $62(p<0.05)$, Taxonomy: Salmonella, Missed cleavage: 1, Peptide Tolerance: +/$0.75 \mathrm{Da}$, Variable modification: none, Fixed modification: none, Enzyme: Trypsin, Mass Values: Monoisotopic.

\section{Quantitative analysis}

Tryptic peak data from MASCOT database searches was tabulated and elemental composition of each peptide fragment was determined using an in-house data analysis software. The process was further automated using a custom VBScript written for Microsoft Excel, which was designed to calculate predicted ${ }^{15} \mathrm{~N}$ peak location based on the primary amino acid sequence of tryptic peptide fragments. ${ }^{14} \mathrm{~N} / 15 \mathrm{~N}$ mixture MS spectrum was used to obtain peak intensity ratio between labeled $\left({ }^{15} \mathrm{~N}\right)$ and unlabeled $\left({ }^{14} \mathrm{~N}\right)$ samples to give relative quantification data. An average of 10 peaks was used to calculate the mean intensity ratios and the error percentage of each protein spot. Significant outliers were manually removed from the data set to prevent them from affecting the results (less than 2\%). To further increase the accuracy of our results, experiments were preformed three times, and the results were the average from the triplicate experiments. Only those proteins that were detected and identified with high confidence in all three independent experiments are listed in Table 1 and Table 2.

\section{Growth and survival analysis of Salmonella}

Strains $\operatorname{SipA}(\mathrm{HF}), \operatorname{SipC}(\mathrm{HF})$ and $\operatorname{SopB}(\mathrm{HF})$ are derivatives of the wild type Salmonella enterica serovar Enteritidis strain SE2472 with a FLAG tag inserted in-frame at the $\mathrm{C}$-terminus of each corresponding protein and have been described previously [36]. Growth analysis of bacteria in LB or LB-like broth was carried out by first inoculating a single colony in $2 \mathrm{ml}$ of either normal $\left({ }^{14} \mathrm{~N}\right)$ or ${ }^{15} \mathrm{~N}$-labeled media and culturing at $37^{\circ} \mathrm{C}$ with shaking at $225 \mathrm{RPM}$ overnight (about 16 hours) [16]. Thirty microliters of the overnight culture were then inoculated into $3 \mathrm{ml}$ fresh normal or ${ }^{15} \mathrm{~N}$-labeled media or LB broth and cultured at $37^{\circ} \mathrm{C}$ with shaking at $225 \mathrm{RPM}$. At $0,2,4$, and 6 hours after inoculation, $100 \mu \mathrm{l}$ of bacterial culture were collected to determine their colony forming unit $(\mathrm{CFU}) / \mathrm{ml}$ by plating. Salmonella grew in normal $\left({ }^{14} \mathrm{~N}\right)$ or ${ }^{15} \mathrm{~N}-$ labeled media as well as in LB broth (data not shown). To study the survival of Salmonella after exposure to $\mathrm{H}_{2} \mathrm{O}_{2}$, $20 \mu \mathrm{l}$ of the overnight culture grown in normal $\left({ }^{14} \mathrm{~N}\right)$ or ${ }^{15} \mathrm{~N}$-labeled media, or LB broth were added to $2 \mathrm{ml}$ of fresh normal $\left({ }^{14} \mathrm{~N}\right)$ or ${ }^{15} \mathrm{~N}$-labeled media, or LB broth containing $5 \mathrm{mM} \mathrm{H}_{2} \mathrm{O}_{2}$. At different time points of incubation, $100 \mu \mathrm{l}$ of bacterial culture were collected, diluted, and plated onto LB agar plates to determine their CFU/ $\mathrm{ml}[16,36]$. Each sample was analyzed in triplicates and the analysis was repeated at least three times.

\section{In vitro studies of the expression of the tagged SPI-1 proteins}

Colonies of tagged strains were inoculated in $1 \mathrm{ml}$ of LB broth and cultured at $37^{\circ} \mathrm{C}$ with shaking at $225 \mathrm{RPM}$ for 
Table 3: Expression proteomics of SE2472 upon exposure to $\mathrm{H}_{2} \mathrm{O}_{2}$, categorized by protein functions.

\begin{tabular}{lc}
\hline Description & Change \\
\hline Glycolysis/Gluconeogenesis & \\
$\quad$ Enolase & $23 \pm 4 \%$ \\
Fructose-1-phosphate kinase & $35 \pm 3 \%$ \\
Fructose-bisphosphate aldolase & $52 \pm 7 \%$ \\
Phosphoenolpyruvate carboxykinase & $330 \pm 40 \%$ \\
Phosphoglycerate kinase & $20 \pm 3 \%$ \\
Phosphoglyceromutase & $-40 \pm 10 \%$ \\
Phosphopyruvate hydratase & $12 \pm 2 \%$ \\
Pyruvate kinase I & $87 \pm 12 \%$
\end{tabular}

\section{TCA Cycle}

Aconitate hydratase 2

$18 \pm 2 \%$

Bifunctional aconitate hydratase

$25 \pm 5 \%$

Citrate synthase

$42 \pm 5 \%$

Malate dehydrogenase

$36 \pm 6 \%$

\begin{tabular}{lc}
\hline Transcription/Translation & \\
Elongation factor G & $9 \pm 2 \%$ \\
Elongation factor Ts & $21 \pm 4 \%$ \\
Elongation factor Tu & $0 \%$ \\
Endonuclease IV & $0 \%$ \\
RNA polymerase sigma factor $r p o S$ & $13 \pm 2 \%$
\end{tabular}

\section{DNA Replication/Repair}

$\begin{array}{ll}\text { ATP-dependent helicase } & 20 \pm 3 \% \\ \text { DNA adenine methylase } & 26 \pm 3 \% \\ \text { DNA mismatch repair protein mutL } & 41 \pm 3 \% \\ \text { Single-strand DNA-binding protein } & 19 \pm 2 \% \\ \text { Uracil-DNA glycosylase } & 27 \pm 2 \%\end{array}$

\begin{tabular}{lc}
\hline Type III Secretion System & \\
Secretory Effector Protein (SipA) & $0 \%$ \\
Translocation Machinery Component (SipC) & $301 \pm 30 \%$ \\
Secretory Effector Protein (SopB) & $-55 \% \pm 7 \%$
\end{tabular}

\section{Pentose Phosphate Pathway}

Deoxyribose-phosphate aldolase $\quad 0 \%$

Glucose-6-phosphate 1-dehydrogenase $\quad 0 \%$

Phosphopentomutase $\quad 0 \%$

2-dehydro-3-deoxygluconokinase $\quad 9 \pm 2 \%$
Table 3: Expression proteomics of SE2472 upon exposure to $\mathrm{H}_{2} \mathrm{O}_{2}$, categorized by protein functions. (Continued)

\begin{tabular}{ll}
\hline Nucleotide synthesis and metabolism & \\
Amidophosphoribosyltransferase & $10 \pm 4 \%$ \\
Thymidine phosphorylase & $-9 \pm 2 \%$ \\
Uridine phosphorylase & $11 \pm 5 \%$ \\
\hline $\begin{array}{l}\text { Amino acid synthesis and metabolism } \\
\text { Shikimate dehydrogenase }\end{array}$ & \\
$\quad$ Succinylornithine transaminase & $12 \pm 3 \%$ \\
Tryptophan synthase & $41 \pm 7 \%$ \\
\hline Representative proteins are shown. & $37 \pm 9 \%$ \\
\hline
\end{tabular}

16 hours. To study the effect of $\mathrm{H}_{2} \mathrm{O}_{2}$ on the protein expression in vitro, $20 \mu \mathrm{l}$ of overnight bacterial cultures were inoculated into $1 \mathrm{ml}$ of antibiotic-free $\mathrm{LB}$ and shaken at $225 \mathrm{RPM}$ at $37^{\circ} \mathrm{C}$ for 4 hours. The bacterial cultures were centrifuged at $5,000 \times \mathrm{g}$ for 5 minutes. The pelleted bacteria were re-suspended in $1 \mathrm{ml}$ of fresh $\mathrm{LB}$ broth (control) or $1 \mathrm{ml}$ of LB broth with $5 \mathrm{mM} \mathrm{H}_{2} \mathrm{O}_{2}$ and shaken at $225 \mathrm{RPM}$ at $37^{\circ} \mathrm{C}$ for an additional 2 hours, and then collected.

To prepare protein samples from Salmonella, bacterial cultures $(1 \mathrm{ml})$ were centrifuged at 5,000 $\times \mathrm{g}$ and $4^{\circ} \mathrm{C}$ for

Table 4: The numbers of bacteria (CFU) in different organs from animals.

\begin{tabular}{|c|c|c|c|c|}
\hline \multirow[t]{3}{*}{ Salmonella strains } & \multicolumn{2}{|c|}{ Colonization (i.p.) } & \multicolumn{2}{|c|}{ Colonization (i.g.) } \\
\hline & \multicolumn{2}{|c|}{ log CFU per organ } & \multicolumn{2}{|c|}{ log CFU per organ } \\
\hline & Liver & Spleen & Liver & Ileum \\
\hline SE2472 & $9.0 \pm 0.5$ & $8.3 \pm 0.5$ & $9.1 \pm 0.5$ & $8.2 \pm 0.5$ \\
\hline $\operatorname{SipA}(\mathrm{HF})$ & $9.1 \pm 0.5$ & $8.2 \pm 0.5$ & $8.9 \pm 0.5$ & $8.3 \pm 0.5$ \\
\hline $\operatorname{SipC}(\mathrm{HF})$ & $9.2 \pm 0.5$ & $8.4 \pm 0.5$ & $9.0 \pm 0.5$ & $8.2 \pm 0.5$ \\
\hline SopB(HF) & $9.0 \pm 0.5$ & $8.4 \pm 0.5$ & $9.2 \pm 0.5$ & $8.1 \pm 0.5$ \\
\hline \multicolumn{5}{|c|}{$\begin{array}{l}\text { * BALB/c mice were either infected intraperitoneally (i.p.) with } 1 \times 10^{4} \\
\text { CFU or intragastrically (i.g.) with } 1 \times 10^{6} \mathrm{CFU} \text { bacteria. A group of } 5 \\
\text { mice was infected and the organs were harvested at } 4 \text { (for i.p. } \\
\text { infection) or } 6 \text { days (for i.g. inoculation) post infection. Each sample } \\
\text { was analyzed in triplicate and the analysis was repeated at least three } \\
\text { times. The CFU of the sample was expressed as the average of the } \\
\text { values obtained. The concentrations of bacteria were recorded as } \\
\text { CFU/ml of organ homogenate. The limit of bacteria detection in the } \\
\text { organ homogenates was } 10 \mathrm{CFU} / \mathrm{ml} \text {. }\end{array}$} \\
\hline
\end{tabular}




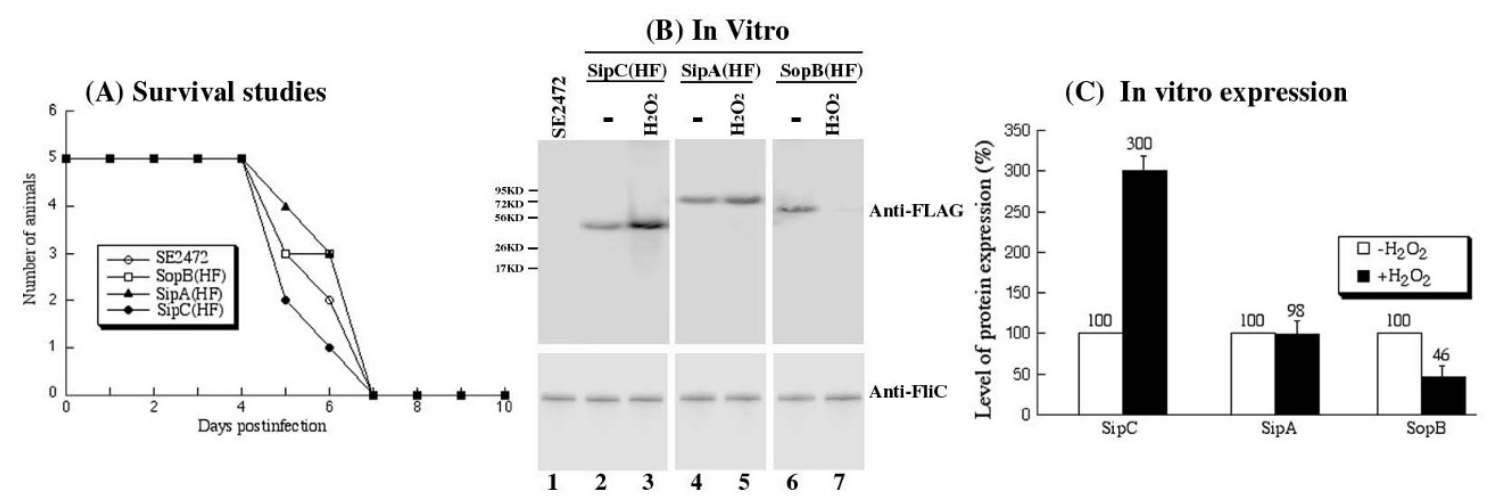

Figure 5 (A) Mortality of BALB/c mice infected with Salmonella strains, (B) Western blot analyses of the synthesis of the tagged proteins from SE2472 (lane 1), SipC(HF) (lanes 2-3), SipA(HF) (lanes 4-5), and SopB(HF) (lanes 6-7), and (C) Effect of the treatment of hydrogen peroxide on the expression of the tagged SPI-1 proteins. (A) Mice (5 animals per group) were infected intragastrically with $1 \times 10^{6} \mathrm{CFU}$ of each bacterial strain. Mortality of mice was monitored for at least 10 days postinfection. (B) The expression of bacterial FliC was used as the internal control. The bacterial strains were grown in LB broth in the absence (-, lanes 2, 4, and 6) and presence of $5 \mathrm{mM} \mathrm{H}_{2} \mathrm{O}_{2}\left(\mathrm{H}_{2} \mathrm{O}_{2}\right.$, lanes 3,5 , and 7$)$ at $37^{\circ} \mathrm{C}$ for 2 hours. SE2472 was grown in the absence of $\mathrm{H}_{2} \mathrm{O}_{2}$ (lane 1). Protein samples were separated in SDS-polyacrylamide gels and reacted with antibodies against the FLAG sequence (top panel) and FliC (low panel). Each lane was loaded with material from $5 \times 10^{7} \mathrm{CFU}$ bacteria. The molecular masses of some of the proteins in the PageRuler protein size markers (Fermentas) are shown and given in kiloDaltons (KD). (C) Cultures of the tagged strains SipA(HF), $\mathrm{SipC}(\mathrm{HF})$, and $\mathrm{SopB}(\mathrm{HF})$ were grown in the absence and presence of $5 \mathrm{mM} \mathrm{H}_{2} \mathrm{O}_{2}$, as described in Methods and Materials. The values, which are the means from triplicate experiments, represent the relative percentage of the level of the tagged proteins from the bacteria grown in the presence of $5 \mathrm{mM} \mathrm{H}_{2} \mathrm{O}_{2}$ to those in the absence of $\mathrm{H}_{2} \mathrm{O}_{2}$.

10 minutes. The pellets were re-suspended in $200 \mu \mathrm{l}$ of bacterial lysis buffer (8 M urea, 2\% CHAPS, and $10 \mathrm{mM}$ Tris, $\mathrm{pH} 8.0$ ), sonicated for 15 seconds three times with an interval of 30 seconds, centrifuged at $5,000 \times \mathrm{g}$ and $4^{\circ} \mathrm{C}$ for 10 minutes, and then transferred into fresh tubes for Western blot analysis.

\section{Infection of cultured macrophages}

RAW264.7 macrophage-like cells (ATCC, Manassas, VA) were infected with stationary phase bacteria at a multiplicity of infection of 50. After incubation for 30 mins, infected cells were washed twice with phosphate-buffered saline (PBS) and incubated in DMEM medium supplemented with gentamicin $(100 \mu \mathrm{g} / \mathrm{ml})$ for 1 hour to eliminate extracellular bacteria. Then the cells were again washed twice with PBS, and incubated in DMEM supplemented with gentamicin $(20 \mu \mathrm{g} / \mathrm{ml})$. At various times postinfection, the cells were collected and resuspended in lysis buffer $(120 \mathrm{mM} \mathrm{NaCl}, 4 \mathrm{mM} \mathrm{MgCl}, 20 \mathrm{mM}$ Tris$\mathrm{HCl}$ [pH 7.5], 1\%, Triton X-100) supplemented with protease inhibitors (complete EDTA-free cocktail, Roche Applied Science, Indianapolis, IN), incubated at $4^{\circ} \mathrm{C}$ for 1 hour, and centrifuged at $18,000 \times \mathrm{g}$ and $4^{\circ} \mathrm{C}$ for $10 \mathrm{~min}$ utes. The pellets that contained bacterial proteins were resuspended in PBS for Western blot analyses.

\section{In vivo studies}

BALB/c mice (6-8 weeks old) were obtained from Jackson Laboratory (Bar Harbor, ME). Overnight bacterial cultures were serially diluted to suitable $\mathrm{CFU} / \mathrm{ml}$ in PBS before infection. To assess the virulence of the tested strains, groups of five mice were either inoculated intragastrically with $1 \times 10^{6} \mathrm{CFU}$ per mouse or intraperitoneally with $1 \times 10^{2} \mathrm{CFU}$ per mouse. Mice were monitored during the course of infection, and those animals that exhibited extreme stress or became moribund were euthanized. For organ colonization experiments, groups of five mice were inoculated intraperitoneally with $1 \times 10^{4}$ or $1 \times 10^{6} \mathrm{CFU}$ per BALB/c mouse of the bacterial strains, and were euthanized at 4 days or 12 hours after inoculation, respectively. Mice were also intragastrically infected with $1 \times 10^{6} \mathrm{CFU}$ per BALB/c mouse of the bacterial strains, and were euthanized at 6 days after inoculation. Organs were collected and homogenized in PBS at $4^{\circ} \mathrm{C}$. An aliquot of each homogenate was used to determine its $\mathrm{CFU} / \mathrm{ml}$ by serial dilution with PBS and plating onto LB agar plates. Each sample was analyzed in triplicate and the analysis was repeated at least three times. The CFU of the sample was expressed as the average of the values obtained. The concentrations of bacteria were recorded as $\mathrm{CFU} / \mathrm{ml}$ of organ homogenate. The limit of bacteria detection in the organ homogenates was $10 \mathrm{CFU} / \mathrm{ml}$. To 

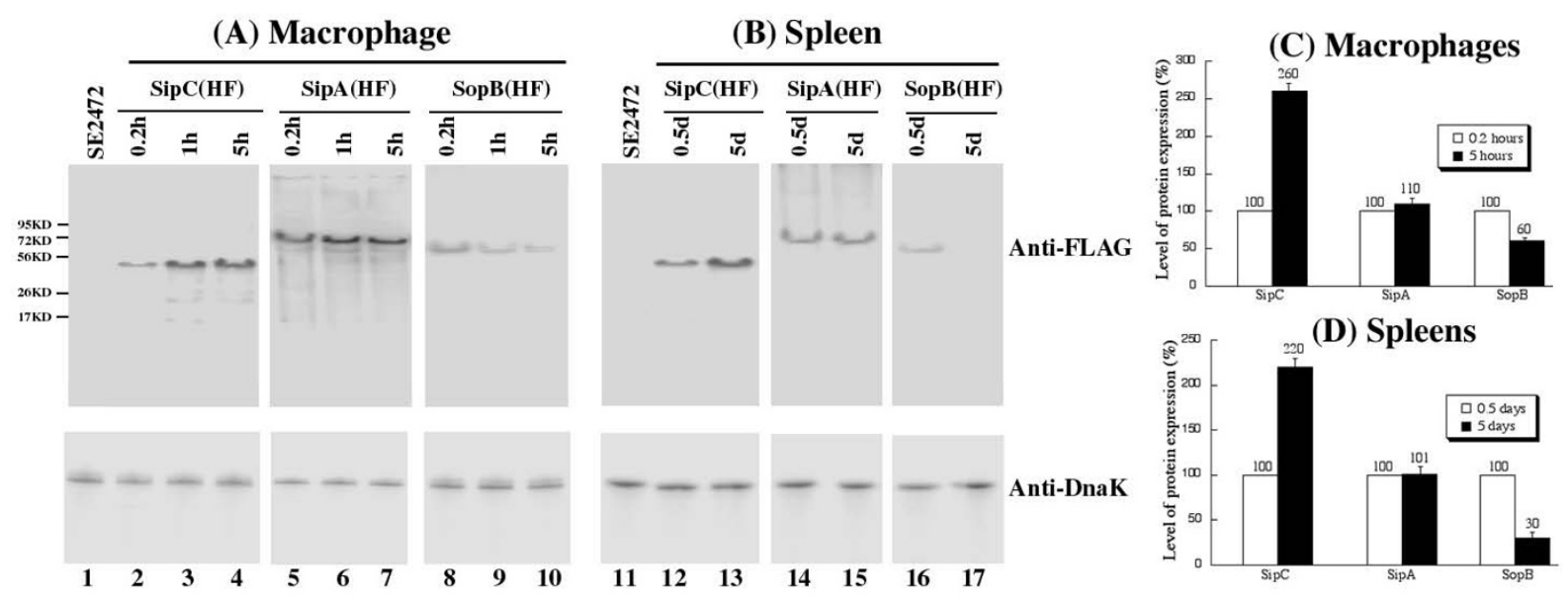

Figure 6 Western blot analyses of the expression of the tagged proteins from bacterial strains SE2472 (lanes 1 and 11), SipC(HF) (lanes 24, 12-13), SipA(HF) (lanes 5-7, 14-15), and SopB(HF)(lanes 8-10, 16-17). In (A), bacterial protein samples were isolated from macrophages at 0.2, 1 , and 5 hours of postinfection. In (B), BALB/C mice were intraperitoneally infected with $1 \times 10^{6}$ and $1 \times 10^{4} \mathrm{CFU}$ of the tagged strains, and internalized bacteria were recovered from the spleen at 0.5 days and 4 days post inoculation, respectively. The expression of bacterial DnaK was used as the internal control. Protein samples were reacted with antibodies against the FLAG sequence (top panel) and DnaK (low panel). Each lane was loaded with material from $5 \times 10^{7}$ CFU bacteria. (C-D). Level of tagged proteins from the bacterial strains recovered from the macrophages and spleens of infected mice as determined in (A) and (B). The values, which are the means of triplicate experiments, represent the relative percentage of the levels of the tagged proteins in the bacteria recovered from macrophages (C) at 5 hours postinfection and from the spleen at 5 days postinoculation (D), as compared to those in the bacteria recovered from macrophages at 0.2 hours postinfection and from spleen at 0.5 days post inoculation, respectively.

prepare protein extracts for Western blot analyses, the homogenates of the spleen samples were centrifuged and the pellets that contained the bacteria were resuspended in PBS, following the procedures described previously [16]. All the experimental procedures with animals were in compliance with the guidelines and policies of the Animal Care and Use Committee (ACUC) of the University of California at Berkeley, and have been approved by the ACUC.

\section{Western blot analyses}

The denatured polypeptides from bacterial lysates were separated on SDS-containing 10-12\% polyacrylamide gels cross-linked with $N, N^{\prime \prime}$-methylenebisacrylamide $(0.05 \%)$, transferred electrically to nitrocellulose membranes (BioRad, Hercules, CA), and reacted in an enzyme-linked immunoassay with a monoclonal anti-FLAG antibody (Sigma, St Louis, MO) and antibodies against Salmonella FliC (BioLegend, San Diego, CA) and DnaK (StressGen, Victoria, British Columbia, Canada), followed by an antimouse IgG conjugated with alkaline phosphatase [16,36]. The membranes were subsequently stained with a chemiluminescent substrate with the aid of a Western chemilu- minescent substrate kit (Amersham Inc, GE Healthcare) and quantified with a STORM840 phosphorimager. Normalization of samples was also carried out by loading total proteins extracted from the same CFU (e.g. $5 \times 10^{7}$ $\mathrm{CFU}$ ) of bacteria in each lane.

\section{Authors' contributions}

$\mathrm{KK}, \mathrm{EY}, \mathrm{GV}, \mathrm{HG}, \mathrm{JS}, \mathrm{FL}$, and SL conceived the study, performed the research, analyzed the results, and wrote the paper. All authors read and approved the final manuscript.

\section{Acknowledgements}

We thank Cindy Loui, Yong Bai, Hongwei Gu, and Huiyuan Jiang for suggestions and excellent technical assistance. K. K., G. V., and E. Y. were partially supported by a Block Grant Predoctoral Fellowship (UC-Berkeley). The research has been supported by grants from USDA (CALR-2005-01892) and NIH (RO1Al041927 and RO1-Al014842).

\section{Author Details}

1 Program in Comparative Biochemistry, University of California, Berkeley, CA 94720, USA and 2Division of Infectious Diseases and Vaccinology, School of Public Health, University of California, Berkeley, CA 94720, USA

Received: 14 September 2009 Accepted: 8 June 2010

Published: 8 June 2010

\section{References}

1. Ohl ME, Miller SI: Salmonella: a model for bacterial pathogenesis. Annu Rev Med 2001, 52:259-274. 
2. Pang $T$, Levine $M M$, Ivanoff $B$, Wain J, Finlay BB: Typhoid fever--important issues still remain. Trends Microbiol 1998, 6(4):131-133.

3. Altekruse SF, Swerdlow DL: The changing epidemiology of foodborne diseases. Am J Med Sci 1996, 311(1):23-29.

4. Galan JE: Salmonella interactions with host cells: type III secretion at work. Annu Rev Cell Dev Biol 2001, 17:53-86.

5. Galan JE, Wolf-Watz H: Protein delivery into eukaryotic cells by type III secretion machines. Nature 2006, 444(7119):567-573.

6. Imlay JA: Pathways of oxidative damage. Annu Rev Microbiol 2003, 57:395-418

7. Imlay JA: Cellular defenses against superoxide and hydrogen peroxide. Annu Rev Biochem 2008, 77:755-776.

8. McCord JM, Fridovich I: The biology and pathology of oxygen radicals. Ann Intern Med 1978, 89(1):122-127.

9. Farr SB, Kogoma T: Oxidative stress responses in Escherichia coli and Salmonella typhimurium. Microbiol Rev 1991, 55(4):561-585.

10. Neidhardt FC: Multigene systems and regulons. In Escherichia coli and Salmonella typhimurium: cellular and molecular biology Edited by: Neidhardt FC, Ingraham JL, Low KB, Magasanik B, Schaechter M, Umbarger HE. Washington, D.C.: American Society of Microbiology; 1987:1313-1317.

11. Walkup LK, Kogoma T: Escherichia coli proteins inducible by oxidative stress mediated by the superoxide radical. J Bacteriol 1989, 171(3):1476-1484

12. Gottesman S: Bacterial regulation: global regulatory networks. Annu Rev Genet 1984, 18:415-441.

13. Mastroeni P, Vazquez-Torres A, Fang FC, Xu Y, Khan S, Hormaeche CE, Dougan G: Antimicrobial actions of the NADPH phagocyte oxidase and inducible nitric oxide synthase in experimental salmonellosis. II. Effects on microbial proliferation and host survival in vivo. J Exp Med 2000, 192(2):237-248

14. De Groote MA, Ochsner UA, Shiloh MU, Nathan C, McCord JM, Dinauer MC, Libby SJ, Vazquez-Torres A, Xu Y, Fang FC: Periplasmic superoxide dismutase protects Salmonella from products of phagocyte NADPHoxidase and nitric oxide synthase. Proc Natl Acad Sci USA 1997, 94(25):13997-14001.

15. Giacomodonato MN, Uzzau S, Bacciu D, Caccuri R, Sarnacki SH, Rubino S, Cerquetti MC: SipA, SopA, SopB, SopD and SopE2 effector proteins of Salmonella enterica serovar Typhimurium are synthesized at late stages of infection in mice. Microbiology 2007, 153(Pt 4):1221-1228.

16. Gong H, Su J, Bai Y, Miao L, Kim K, Yang Y, Liu F, Lu S: Characterization of the expression of Salmonella Type III secretion system factor Prgl, SipA, SipB, SopE2, SpaO, and SptP in cultures and in mice. BMC Microbiol 2009, 9:73.

17. Lober S, Jackel D, Kaiser N, Hensel M: Regulation of Salmonella pathogenicity island 2 genes by independent environmental signals. Int J Med Microbiol 2006, 296(7):435-447.

18. Ellermeier JR, Slauch JM: Adaptation to the host environment: regulation of the SPI1 type III secretion system in Salmonella enterica serovar Typhimurium. Curr Opin Microbiol 2007, 10(1):24-29.

19. Eriksson S, Lucchini S, Thompson A, Rhen M, Hinton JC: Unravelling the biology of macrophage infection by gene expression profiling of intracellular Salmonella enterica. Mol Microbiol 2003, 47(1):103-118.

20. Faucher SP, Porwollik S, Dozois CM, McClelland M, Daigle F: Transcriptome of Salmonella enterica serovar Typhi within macrophages revealed through the selective capture of transcribed sequences. Proc Natl Acad Sci USA 2006, 103(6):1906-1911.

21. Hautefort I, Thompson A, Eriksson-Ygberg S, Parker ML, Lucchini S, Danino V, Bongaerts RJ, Ahmad N, Rhen M, Hinton JC: During infection of epithelial cells Salmonella enterica serovar Typhimurium undergoes a time-dependent transcriptional adaptation that results in simultaneous expression of three type 3 secretion systems. Cell Microbiol 2008, 10(4):958-984.

22. Huang X, Xu H, Sun X, Ohkusu K, Kawamura Y, Ezaki T: Genome-wide scan of the gene expression kinetics of Salmonella enterica Serovar Typhi during hyperosmotic Stress. Int J Mol Sci 2007, 8:1 16-135.

23. Gantois I, Ducatelle R, Pasmans F, Haesebrouck F, Hautefort I, Thompson A, Hinton JC, Van Immerseel F: Butyrate specifically down-regulates salmonella pathogenicity island 1 gene expression. Appl Environ Microbiol 2006, 72(1):946-949.
24. Becker D, Selbach M, Rollenhagen C, Ballmaier M, Meyer TF, Mann M, Bumann D: Robust Salmonella metabolism limits possibilities for new antimicrobials. Nature 2006, 440(7082):303-307.

25. Adkins JN, Mottaz HM, Norbeck AD, Gustin JK, Rue J, Clauss TR, Purvine SO, Rodland KD, Heffron F, Smith RD: Analysis of the Salmonella typhimurium proteome through environmental response toward infectious conditions. Mol Cell Proteomics 2006, 5(8):1450-1461

26. Shi L, Adkins JN, Coleman JR, Schepmoes AA, Dohnkova A, Mottaz HM Norbeck AD, Purvine SO, Manes NP, Smallwood HS, et al: Proteomic analysis of Salmonella enterica serovar typhimurium isolated from RAW 264.7 macrophages: identification of a novel protein that contributes to the replication of serovar typhimurium inside macrophages. $J$ Biol Chem 2006, 281(39):29131-29140.

27. Manes NP, Gustin JK, Rue J, Mottaz HM, Purvine SO, Norbeck AD, Monroe ME, Zimmer JS, Metz TO, Adkins JN, et al:: Targeted protein degradation by Salmonella under phagosome-mimicking culture conditions investigated using comparative peptidomics. Mol Cell Proteomics 2007, 6(4):717-727.

28. Ansong C, Yoon H, Norbeck AD, Gustin JK, McDermott JE, Mottaz HM, Rue J, Adkins JN, Heffron F, Smith RD: Proteomics analysis of the causative agent of typhoid fever. J Proteome Res 2008, 7(2):546-557.

29. Christman MF, Morgan RW, Jacobson FS, Ames BN: Positive control of a regulon for defenses against oxidative stress and some heat-shock proteins in Salmonella typhimurium. Cell 1985, 41(3):753-762.

30. Morgan RW, Christman MF, Jacobson FS, Storz G, Ames BN: Hydrogen peroxide-inducible proteins in Salmonella typhimurium overlap with heat shock and other stress proteins. Proc Natl Acad Sci USA 1986, 83(21):8059-8063.

31. Ishihama Y, Sato T, Tabata T, Miyamoto N, Sagane K, Nagasu T, Oda Y. Quantitative mouse brain proteomics using culture-derived isotope tags as internal standards. Nat Biotechnol 2005, 23(5):617-621.

32. Ong SE, Mann M: A practical recipe for stable isotope labeling by amino acids in cell culture (SILAC). Nat Protoc 2006, 1(6):2650-2660

33. Lu S, Manges AR, Xu Y, Fang FC, Riley LW: Analysis of virulence of clinical isolates of Salmonella enteritidis in vivo and in vitro. Infect Immun 1999, 67(11):5651-5657.

34. Browne TR, Van Langenhove A, Costello CE, Biemann K, Greenblatt DJ: Kinetic equivalence of stable-isotope-labeled and unlabeled phenytoin. Clin Pharmacol Ther 1981, 29(4):511-515.

35. De Leenheer AP, Thienpont LM: Applications of isotope-dilution massspectrometry in clinical chemistry, pharmacokinetics, and toxicology. Mass Spectrom Rev 1922, 11:249-307.

36. Su J, Gong H, Lai J, Main A, Lu S: Potassium transporter Trk and external potassium modulate Salmonella protein secretion and virulence. Infect Immun 2009, 77:667-675.

37. Aebersold R, Mann M: Mass spectrometry-based proteomics. Nature 2003, 422(6928):198-207.

38. Loui C, Chang AC, Lu S: Role of the ArCAB two-component system in the resistance of Escherichia coli to reactive oxygen stress. BMC Microbiol 2009, 9:183

39. VanBogelen RA, Kelley PM, Neidhardt FC: Differential induction of heat shock, SOS, and oxidation stress regulons and accumulation of nucleotides in Escherichia coli. J Bacteriol 1987, 169(1):26-32.

40. Desnoyers G, Morissette A, Prevost K, Masse E: Small RNA-induced differential degradation of the polycistronic mRNA iscRSUA. Embo J 2009, 28(11):1551-1561

41. Hebrard M, Viala JP, Meresse S, Barras F, Aussel L: Redundant hydrogen peroxide scavengers contribute to Salmonella virulence and oxidative stress resistance. J Bacterio/ 2009, 191(14):4605-4614

42. Zhou D, Mooseker MS, Galan JE: An invasion-associated Salmonella protein modulates the actin-bundling activity of plastin. Proc Natl Acad SciUSA 1999, 96(18):10176-10181.

43. Lilic M, Galkin VE, Orlova A, VanLoock MS, Egelman EH, Stebbins CE: Salmonella SipA polymerizes actin by stapling filaments with nonglobular protein arms. Science 2003, 301(5641):1918-1921.

44. Brawn LC, Hayward RD, Koronakis V: Salmonella SPI1 effector SipA persists after entry and cooperates with a SPI2 effector to regulate phagosome maturation and intracellular replication. Cell Host Microbe 2007, 1(1):63-75

45. Figueiredo JF, Lawhon SD, Gokulan K, Khare S, Raffatellu M, Tsolis RM, Baumler AJ, McCormick BA, Adams LG: Salmonella enterica Typhimurium 
SipA induces CXC-chemokine expression through p38 MAPK and JUN pathways. Microbes Infect 2009, 11:302-310.

46. Lee CA, Silva M, Siber AM, Kelly AJ, Galyov E, McCormick BA: A secreted Salmonella protein induces a proinflammatory response in epithelial cells, which promotes neutrophil migration. Proc Natl Acad Sci USA 2000, 97(22):12283-12288.

47. Shi L, Chowdhury SM, Smallwood HS, Yoon H, Mottaz-Brewer HM, Norbeck AD, McDermott JE, Clauss TR, Heffron F, Smith RD, et al: Proteomic investigation of the time course responses of RAW 264.7 macrophages to infection with Salmonella enterica. Infect Immun 2009, 77(8):3227-3233.

48. Patel JC, Hueffer K, Lam TT, Galan JE: Diversification of a Salmonella virulence protein function by ubiquitin-dependent differential localization. Cell 2009, 137(2):283-294.

49. Terebiznik MR, Vieira OV, Marcus SL, Slade A, Yip CM, Trimble WS, Meyer T, Finlay BB, Grinstein S: Elimination of host cell Ptdlns $(4,5) \mathrm{P}(2)$ by bacterial $\mathrm{SigD}$ promotes membrane fission during invasion by Salmonella. Nat Cell Biol 2002, 4(10):766-773.

50. Marcus SL, Knodler LA, Finlay BB: Salmonella enterica serovar Typhimurium effector SigD/SopB is membrane-associated and ubiquitinated inside host cells. Cell Microbio/ 2002, 4(7):435-446.

51. Norris FA, Wilson MP, Wallis TS, Galyov EE, Majerus PW: SopB, a protein required for virulence of Salmonella dublin, is an inositol phosphate phosphatase. Proc Natl Acad Sci USA 1998, 95(24):14057-14059.

52. Drecktrah D, Knodler LA, Galbraith K, Steele-Mortimer O: The Salmonella SPI1 effector SopB stimulates nitric oxide production long after invasion. Cell Microbiol 2005, 7(1):105-113.

53. Hernandez LD, Hueffer K, Wenk MR, Galan JE: Salmonella modulates vesicular traffic by altering phosphoinositide metabolism. Science 2004, 304(5678):1805-1807.

54. Steele-Mortimer O, Knodler LA, Marcus SL, Scheid MP, Goh B, Pfeifer CG Duronio V, Finlay BB: Activation of Akt/protein kinase B in epithelial cells by the Salmonella typhimurium effector sigD. J Biol Chem 2000, 275(48):37718-37724.

55. Hayward RD, Koronakis V: Direct nucleation and bundling of actin by the SipC protein of invasive Salmonella. Embo J 1999, 18(18):4926-4934.

56. Scherer CA, Cooper E, Miller SI: The Salmonella type III secretion translocon protein $\mathrm{SspC}$ is inserted into the epithelial cell plasma membrane upon infection. Mol Microbio/ 2000, 37(5):1133-1145.

57. Ly KT, Casanova JE: Mechanisms of Salmonella entry into host cells. Cell Microbiol 2007, 9(9):2103-2111.

58. Chang J, Myeni SK, Lin TL, Wu CC, Staiger CJ, Zhou D: SipC multimerization promotes actin nucleation and contributes to Salmonella-induced inflammation. Mol Microbiol 2007, 66(6):1548-1556.

59. Lara-Tejero M, Galan JE: Salmonella enterica serovar typhimurium pathogenicity island 1-encoded type III secretion system translocases mediate intimate attachment to nonphagocytic cells. Infect Immun 2009, 77(7):2635-2642.

60. Ansong C, Yoon H, Porwollik S, Mottaz-Brewer H, Petritis BO, Jaitly N, Adkins JN, McClelland M, Heffron F, Smith RD: Global systems-level analysis of $\mathrm{Hfq}$ and $\mathrm{SmpB}$ deletion mutants in Salmonella: implications for virulence and global protein translation. PLoS One 2009, 4(3):e4809.

doi: $10.1186 / 1471-2180-10-166$

Cite this article as: Kim et al., Mass spectrometry-based quantitative proteomic analysis of Salmonella enterica serovar Enteritidis protein expression upon exposure to hydrogen peroxide BMC Microbiology 2010, 10:166

\section{Submit your next manuscript to BioMed Central} and take full advantage of:

- Convenient online submission

- Thorough peer review

- No space constraints or color figure charges

- Immediate publication on acceptance

- Inclusion in PubMed, CAS, Scopus and Google Scholar

- Research which is freely available for redistribution

Submit your manuscript at www.biomedcentral.com/submit
C Biomed Central 